\title{
DAUBERT AND THE DISAPPEARING JURY TRIAL
}

\author{
Allan Kanner ${ }^{*}$ and M. Ryan Casey ${ }^{* *}$
}

\section{Table of Contents}

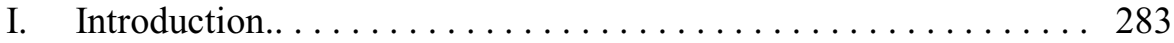

II. Background: Experts. . . . . . . . . . . . . . . . . . . . 284

III. Daubert v. Merrell Dow Pharmaceuticals, Inc.............. 286

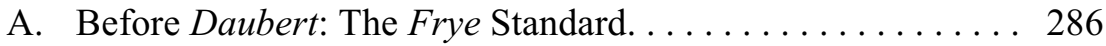

B. A Case About Bendectin.... . . . . . . . . . . . . . . . . . . 287

C. Daubert and the Goal of Liberalizing the Admissibility of

Evidence. . . . . . . . . . . . . . . . . . . . . . 288

D. Daubert's Directive to the Federal Judiciary. . . . . . . . . . 290

E. Does Daubert Undermine the Seventh Amendment?. . . . . . . 291

IV. Daubert's Evolution: The Companion Cases............... 292

A. General Electric Co. v. Joiner. . . . . . . . . . . . . . . . . . 293

B. Kuhmo Tire Co. v. Carmichael. ... . . . . . . . . . . . . . 293

C. The Federal Rules of Evidence. . . . . . . . . . . . . . . . . 294

D. Later Case Law. . . . . . . . . . . . . . . . . . . . . . . . 294

V. Corporate Influence in Science: The "Junk Science" Revolution. . 296

VI. The Judiciary Today and the Abuse of Daubert. . . . . . . . . . 297

A. The Incentive to Prevent Jury Trials. . . . . . . . . . . . . . 299

1. Increasing Caseloads. . . . . . . . . . . . . . . . . . . 299

2. Inexperienced Trial Judges. . . . . . . . . . . . . . . 300

3. The Judge as Manager. . . . . . . . . . . . . . . . . . . . . . . 302

4. The Pro-Business Judge. . . . . . . . . . . . . . . . . . . . . . . 304

5. Loss of Focus. . . . . . . . . . . . . . . . . . . . . . . . 305

B. Daubert: The Opportunity to Prevent Jury Trials........ 306

C. Even Peer-Reviewed Evidence is Excluded Under Daubert. . 308

\footnotetext{
* Founding Member, Kanner \& Whiteley, L.L.C., New Orleans, LA; Senior Lecturing Fellow, Duke Law School, and Adjunct Professor of Law, Tulane Law School; B.A., U. Pennsylvania, 1975; J.D., Harvard Law School, 1979. The ideas expressed in this article are the authors' and do not reflect the views of any clients.

** Associate, Kanner \& Whiteley, L.L.C., New Orleans, LA; B.A., College of William and Mary, 2000 ; J.D., University of Oregon School of Law, 2006. The ideas expressed in this article are the authors' and do not reflect the views of any clients.
} 
VII. Doctored Daubert: The Effects on the Legal System and Society.. 313

A. Evidence Exclusion and the Chilling Effect on Plaintiffs.. . . 314

B. Chilling Effect on Scientists. ............... 316

C. Daubert Undermines the Courtroom as a Public Hearing Mechanism. ......................... 316

D. A Waste of Judicial Resources: The Rise in Forum Fighting. 317

E. Daubert's Damage to Collateral Estoppel... . . . . . . . . . . 319

F. Daubert Abuse Creeping into Regulatory Agencies... . . . . 320

VIII. Proposed Changes to the Daubert Paradigm.. . . . . . . . . . . . 321

A. Meaningful Appellate Review.................... 321

B. A More Liberal Standard in Novel Cases. . . . . . . . . . . 322

C. A Critique of "Non-traditional" Means.. . . . . . . . . . . . 322

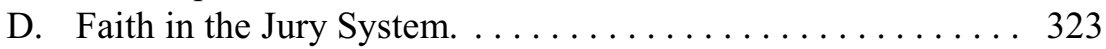

IX. What to Do in the Meantime: Winning the Expert Battle. . . . . . 323

A. Case and Forum Selection.................. . 324

B. Discovery Strategy. .................... 325

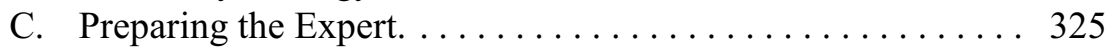

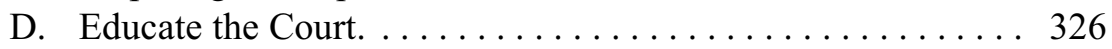

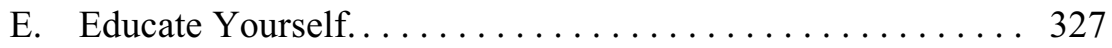

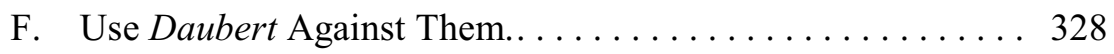

X. Conclusion. .............................. 329 


\section{INTRODUCTION}

In Kafka's Before the Law, ${ }^{1}$ a man is arrested for a crime unknown to him and is tried in a court he does not recognize. To help explain the situation to the bewildered prisoner, a parable is related about a man seeking admittance to the Law. He comes before the gate of the Law and is told by the gatekeeper that it is possible to enter, but not at that moment. ${ }^{2}$ The man pleads with the gatekeeper but is denied entry. ${ }^{3} \mathrm{He}$ spends his entire life before the gate, and just before his death, asks the gatekeeper, "Everyone strives after the law ..., so how does it happen that in these many years no one but myself has ever begged admittance?"4 The gatekeeper sees that the man is near death, and shouts at him, "No one else could ever be admitted here, since this gate was made only for you. I am now going to shut it."

In Daubert v. Merrell Dow Pharmaceuticals, Inc., ${ }^{6}$ the Supreme Court unintentionally empowered federal judges with the seemingly divine powers of Kafka's gatekeeper. Meant to liberalize the admittance of scientific evidence, ${ }^{7}$ the actual result has been the exact opposite. The gatekeeping role bestowed upon the judiciary has blocked more court access than it has enabled. Judges, shouldering a slew of incentives to prevent a jury trial from taking place in their courts, are now empowered with a tool to do just that: the Daubert hearing. But plaintiffs' attorney (against whom the Daubert challenge is most used) must recognize that the gate, however outwardly insurmountable, ultimately exists — as in Kafka's parable — only for them. ${ }^{8}$ Despite Daubert, and the disastrous effects it has wrought upon the civil

1. Franz Kafka, Before the Law, in The Complete Stories 3 (Nahum N. Glatzer ed., Willa \& Edwin Muir trans., 2d ed. 1995).

2. Id. at 3 .

3. $I d$.

4. Id. at 4 .

5. Id. at 3-4.

6. 509 U.S. 579 (1993).

7. See, e.g., Martin L.C. Feldman, May I Have The Next Dance, Mrs. Frye?, 69 TuL. L. Rev. 793, 803 (1995); Harvard Law Review Ass'n, The Supreme Court, 1992 Term: Leading Cases, 107 Harv. L. REV. 144, 254-64 (1993).

8. This is not to deny that in some cases defendants' use of junk science has been stopped with a Daubert motion. Nor is it to suggest that Daubert rulings are adversely threatened against both parties by settlement-minded judges. However, the primary use of Daubert has been to dismiss plaintiffs' cases. See generally Project on Scientific Knowledge and Public Policy, Tellus Inst., Daubert: The Most Influential Supreme Court Ruling You've Never Heard Of 4 (2003), available at http:// www.defendingscience.org/upload/Daubert-The-Most-Influential-Supreme-Court-Decision-You-ve-NeverHeard-Of-2003.pdf [hereinafter Project on Scientific Knowledge and Public Policy]. 
justice system, techniques and maneuvers exist to assist a plaintiff in avoiding the same fate as Kafka's doomed protagonist.

This Article examines the background of expert witness testimony, Daubert, and its companion cases. Next, the Article explores corporate influence in science - and how Daubert has allowed this corporate influence to erode true science. Incentives, some benign and some of sheer bias, were created which allow judges to use Daubert to kill cases. This Article first looks at what the effect has been on the civil justice system and then offers some solutions and practical advice for attorneys facing a daunting Daubert hearing.

\section{BACKGROUND: EXPERTS}

The Federal Rules of Evidence contain clear-cut rules concerning expert testimony and who might be considered an expert. Essentially, an expert is one who possesses specialized knowledge that helps a juror understand a concept outside of the ordinary juror's everyday experience. ${ }^{9}$ Federal Rule of Evidence 702 provides the following description:

Rule 702. Testimony by Experts

If scientific, technical, or other specialized knowledge will assist the trier of fact to understand the evidence or to determine a fact in issue, a witness qualified as an expert by knowledge, skill, experience, training, or education, may testify thereto in the form of an opinion or otherwise, if (1) the testimony is based upon sufficient facts or data, (2) the testimony is the product of reliable principles and methods, and (3) the witness has applied the principles and methods reliably to the facts of the case. $^{10}$

The Rules dictate that an expert must inform the case in a certain way. The expert's opinion should be relevant to the facts of the case and must be based on principles, methods, and techniques that have been subjected to peer review and proven reliable. Rule 703 provides:

Rule 703. Bases of Opinion Testimony by Experts

The facts or data in the particular case upon which an expert bases an opinion or inference may be those perceived by or made known to the expert at or before the hearing. If of a type reasonably relied upon by experts in the particular field in forming opinions or inferences upon the subject, the facts or data need not be admissible in evidence in order for the opinion or inference to be admitted. Facts or data that are otherwise inadmissible shall not be disclosed to the jury by the

9. Allan Kanner, Environmental and Toxic Tort Trials $\S 4.16$ (2d ed. Supp. 2004).

10. FED. R. Evid. 702. 
proponent of the opinion or inference unless the court determines that their probative value in assisting the jury to evaluate the expert's opinion substantially outweighs their prejudicial effect. ${ }^{11}$

There are exceptions. ${ }^{12}$ For instance, non-experts are allowed to offer expert-like opinions. ${ }^{13}$ Landowners or business owners may offer opinions valuing damages done to their property ${ }^{14}$ or business. ${ }^{15}$ Experts may also be called upon (in their expert capacity) to provide factual, not opinion testimony. ${ }^{16}$ On the other hand, some expert proof may run afoul of other rules. For example, experts cannot give unduly prejudicial testimony. ${ }^{17}$ Also, experts cannot give legal opinions in most cases. ${ }^{18}$

11. Id. at 703 .

12. See KANNER, supra note $9, \S 4.02(1)$, at 8-10.

13. FED. R. EvID. 701 (allowing non-expert opinions or inferences "which are (a) rationally based on the perception of the witness, (b) helpful to a clear understanding of the witness' testimony or the determination of a fact in issue, and (c) not based on scientific, technical or other specialized knowledge within the scope of Rule 702").

14. See, e.g., Klapmeier v. Telecheck Int'1, Inc., 482 F.2d 247, 253 (8th Cir. 1973) (allowing owner to testify as to the value of his property); United States v. Sowards, 370 F.2d 87, 92 (10th Cir. 1966) (evaluating when non-experts' opinion evidence has probative value and should be admitted by the court).

15. See, e.g., Boehm v. Fox, 473 F.2d 445, 448-49 (10th Cir. 1973) (allowing dairy owner's opinion on average pay to calculate compensatory damages).

16. See, e.g., Brown v. Ryan's Family Steak House, Inc., 113 F. App'x 512, 516 (4th Cir. 2004). In Brown, a former employee brought a Title VII action. Id. at 514. The proceedings can be summarized as follows: The employer moved to dismiss and compel arbitration pursuant to an arbitration agreement executed by the minor employee's guardian and great-great aunt, Mrs. Gassaway. Id. The employee countered that her guardian, now deceased, lacked the requisite mental capacity to enter into a binding contract when the arbitration agreement was executed. Id. at 514-16. In support, the employee offered testimony from the guardian's treating physician of sixteen years, Dr. John Sanders, who opined that the guardian was in mental decline due to brain atrophy during the relevant time. The district court denied the employer's motion to dismiss on magistrate's recommendation, and the employer appealed. Id. The admissibility was affirmed. Id. at 517. The physician's diagnosis of the guardian's ailments was not required to satisfy Daubert because the physician was a fact witness describing the patient's condition. The physician's opinion of the guardian's mental capacity was admissible as a lay opinion under Rule 701. Id. at 515-17. The court noted:

Furthermore, Dr. Sanders is the most qualified person available to testify to Mrs. Gassaway's mental capacity. Gassaway has passed away and is not available for further medical examination. Dr. Sanders was her treating physician for sixteen years. The fact that his practice is internal medicine rather than neurology does not negate the fact that he is a qualified physician with more first-hand knowledge concerning Gassaway's physical and mental wellId. at 516

being than any other medical professional.

17. FED. R. Evid. 403.

18. See, e.g., United States v. Phillips, 478 F.2d 743, 746 n.6 (9th Cir. 1973) (excluding expert testimony that mixed questions of law and questions of fact); N.Y. v. Westwood-Squib Pharm. Co., No. 90-CV-1324C, 2001 U.S. Dist. LEXIS 11765, at*30-31 (W.D.N.Y. June 23, 2001) (disallowing legal opinion on allocation of hazardous waste liabilities among responsible parties). 
Daubert, as explained below, was a reaction to the perceived proliferation of bad experts in federal courts. At the time, some legal scholars felt that some putative experts were neither objective nor neutral. ${ }^{19}$ Scientists, of course, work hard at being objective because of the limits and goals of their scientific disciplines, but this does not mean that personal preference, greed, or ideology never clouds their research. The scientific community has its share of ambition, censorship, prejudice, plagiarism, and manipulation of data. ${ }^{20}$ Against this backdrop, Daubert makes sense. But the road to hell is paved with good intentions.

\section{Daubert V. Merrell Dow Pharmaceuticals, InC.}

\section{A. Before Daubert: The Frye Standard}

Judge Learned Hand observed at the turn of the century that expert evidence is worthless to a factfinder if it is not reliable. ${ }^{21}$ Since evidence that is not reliable is not relevant, standards for reliability had to be established. ${ }^{22}$ The federal judiciary, seeking a standard regarding the reliability of scientific proof, eventually settled on the standard espoused in Frye v. United States. ${ }^{23}$

In Frye, the trial court in a murder trial refused to admit the defendant's systolic blood pressure test to show his truthfulness. ${ }^{24}$ The defendant was convicted, and the D.C. Circuit Court of Appeals heard the case on the issue of whether the test ought to have been admitted. ${ }^{25}$ In the following famous passage, the court notes:

Just when a scientific principle or discovery crosses the line between the experimental and demonstrable stages is difficult to define. Somewhere in this twilight zone the evidential force of the principle must be recognized, and while courts will go a long way in admitting expert testimony deduced from a wellrecognized scientific principle or discovery, the thing from which the deduction is made must be sufficiently established to have gained general acceptance in the particular field in which it belongs. ${ }^{26}$

19. See, e.g., Alexander Kohn, False Prophets (1986); William Broad \& Nicholas Wade, Betrayers of the Truth (1982).

20. See supra note 19.

21. Learned Hand, Historical and Practical Considerations Regarding Expert Testimony, 15 HARV. L. REV. 40, 55-56 (1901).

22. $I d$.

23. 293 F. 1013, 1014 (D.C. Cir. 1923).

24. Id.

25. $I d$.

26. Id. 
Under Frye, a theory must undergo two stages before it can be accepted as reliable in a courtroom. The scientific community first develops a theory (presumably using the scientific method). After the results of the theory are published, it is then subjected to peer review. In the second stage, peer review accepts the theory, allowing its use in a courtroom. The Frye standard for peer review acceptance is "general acceptance" in the relevant scientific community. ${ }^{27}$ Thus, lawyers seeking to admit evidence or expert testimony under the Frye standard must show "general acceptance" of the theory. This can be done by offering other judicial decisions, testimony by a scientist's peers, and scientific journals or other publications.

Novel theories and novel scientific evidence were the most unlikely candidates to pass the Frye standard. As one commentator noted:

Polygraphy, graphology, hypnotic and drug induced testimony, voice stress analysis, voice spectrograms, ion microprobe mass spectroscopy, infrared sensing of aircraft, retesting of breath samples for alcohol content, psychological profiles of battered women, and child abusers, post-traumatic stress disorder as indicating rape, astronomical calculations, and blood group typing, all have fallen prey to [Frye's] influence. $^{28}$

The issuance of the Federal Rules of Evidence in 1975 hatched concerns that Frye's discriminatory application against novel theories went against the spirit of the Rules. Decades later, the Supreme Court would address these concerns.

\section{B. A Case About Bendectin}

Bendectin was an anti-nausea drug marketed by Merrell Dow Pharmaceuticals with pregnant women in mind. Instances arose whereby some children born to mothers who had ingested Bendectin suffered serious birth defects. The question remained whether Bendectin caused those birth defects. ${ }^{29}$ In 1993, the parents of two children with serious birth defects born to mothers who had ingested Bendectin sued Merrell Dow. ${ }^{30}$ The case was removed to federal court, where the defendant produced expert testimony at a pre-trial hearing that Bendectin in fact causes no birth defects. ${ }^{31}$ The court

27. See id.

28. McCormick on Evidence $\S 203$, at 363 (John W. Strong ed., 4th ed. 1992).

29. Daubert v. Merrell Dow Pharm., Inc., 509 U.S. 579, $582-83$ (1993).

30. Id. at 582 .

31. Id. 
turned to consider the admissibility of the testimony of the plaintiff's expert interpreting epidemiological studies by others. ${ }^{32}$ Based on the defendant's expert, the plaintiff's expert testimony was rejected by the trial court and the Ninth Circuit Court of Appeals under the Frye standard. ${ }^{33}$ The case was appealed to the U.S. Supreme Court.

\section{Daubert and the Goal of Liberalizing the Admissibility of Evidence}

The Supreme Court held that the adoption of Rules 702 and 703 effectively liberalized and overruled the Frye test, "[g]iven the Rules" permissive backdrop and their inclusion of a specific rule on expert testimony that does not mention 'general acceptance."”34 It replaced Frye's "general acceptance" test with a case-specific inquiry by the trial judge, applicable not only to "unconventional evidence," but also to other scientific testimony. In its reasoning, the Court noted that Rule 702 superseded Frye's "general acceptance" test because it was deemed at odds with the "liberal thrust" of the Federal Rules of Evidence. After reviewing Rule 702, the Court noted that "[n]othing in the text of this Rule establishes 'general acceptance' as an absolute prerequisite to admissibility." "35 When Frye provided the governing test, the standard for the admission of expert testimony focused upon the question of scientific consensus rather than the quality of the scientific method. The Supreme Court characterized the Frye test as "austere." 36 Specifically, Justice Blackmun explained that:

The drafting history [of the Federal Rules Evidence] makes no mention of Frye, and a rigid "general acceptance" requirement would be at odds with the "liberal thrust" of the Federal Rules and their "general approach of relaxing the traditional barriers to 'opinion' testimony." 37

A unanimous Court agreed that nothing in the text of Rule 702 established "general acceptance" as an absolute prerequisite to admissibility. ${ }^{38}$

32. Id. at $583-85$.

33. $I d$.

34. Id. at 589

35. Daubert, 509 U.S. at 588 (citing FED. R. Evid. 702). For good discussions of these issues, see Nat'l Conference on Sci. and the Law, Daubert-Joiner-Kumho: The Brave New World of Expert Evidence, 15 Toxics L. ReP. (BNA) 1213 (2000); Leslie Lunney, Protecting Juries From Themselves: Restricting the Admission of Expert Testimony in Toxic Tort Cases, 48 SMU L. Rev. 103 (1994).

36. See Daubert, 509 U.S. at 589.

37. Id. at 588 (citing Beech Aircraft Corp. v. Rainey, 488 U.S. 153, 169 (1988)).

38. Id. 
Consequently, the majority sought to articulate an alternative (and ostensibly more liberal) standard in accordance with the Federal Rules of Evidence.

Rule 702 provides that "[i]f scientific, technical, or other specialized knowledge will assist the trier of fact to understand the evidence or to determine a fact in issue," an expert "may testify thereto." 39 The Daubert Court interpreted this rule to impose two distinct requirements in the case of scientific expert evidence. First, the evidence must be reliable - that is, the underlying methodology and procedure from which evidence is derived (not the conclusion drawn) must be based on scientific knowledge. The district court acts as a gatekeeper under Rule 104(a) and makes a preliminary assessment of whether the reasoning or methodology underlying the testimony is scientifically valid. In deciding if the testimony is scientifically valid, the court looks to many factors, including whether the theory or technique can and has been tested, whether it has been subjected to peer review, the known or potential rate of error, and whether it has been generally accepted. Second, the evidence must be relevant - that is, it must assist the trier of fact either in understanding the evidence or in determining a fact in issue. ${ }^{40}$

The Court in Daubert added that federal courts would also evaluate admissibility under other applicable federal rules. It specifically noted Rule 703, which limits the facts or data upon which experts may rely to those "reasonably relied upon by experts in the particular field," 41 and Rule 403, which permits the court to exclude relevant evidence if "its probative value is substantially outweighed by the danger of unfair prejudice, confusion of the issues, or misleading the jury." ${ }^{\prime 2}$ In closing, the Daubert Court addressed the defendants' concern that abandonment of the general acceptance test would result in a "free-for-all" before the jury. ${ }^{43}$ Defendants would continue to have available the traditional means of attacking admissible evidence: "[v]igorous cross-examination, presentation of contrary evidence, and careful instruction

\footnotetext{
39. FED. R. Evid. 702.

40. See Daubert, 509 U.S. at 589-91.

41. Id. at 595; see also FED. R. EvID. 703.

42. Daubert, 509 U.S. at 595; FED. R. Evid. 403.

43. See id. at 595, 596-97.
} 
on the burden of proof." 44 Thus, the goal of Daubert was to make it easier, not harder, for plaintiffs to present novel theories to juries.

\section{Daubert's Directive to the Federal Judiciary}

Daubert is a confusing case for the federal judiciary to interpret. Justice Rehnquist, in his dissent, noted that "[q]uestions arise simply from reading... the Court's opinion, and countless more questions will surely arise when hundreds of district judges try to apply its teaching to particular offers of expert testimony." 45 What exactly constituted the directive to the federal judiciary has been the subject of countless law review articles, ${ }^{46}$ and the Supreme Court has revisited the case on multiple occasions. ${ }^{47}$

Under Daubert, a trial court judge faced with a proffer of expert scientific testimony must determine whether the expert is proposing to testify to (1) scientific knowledge that (2) will assist the trier of fact to understand or determine a fact at issue. ${ }^{48}$ The Daubert Court noted that many factors will bear on the inquiry and stated that it was not setting out a definitive checklist or test. ${ }^{49}$ Because Rule 702 clearly implies some degree of regulation, the Daubert Court imposed conditions: "[t]he subject of an expert's testimony must be "scientific . . knowledge." That is, "an inference or assertion must

44. Id. at 596. Since Daubert was decided, several circuits have applied it in affirming district court exclusions of expert testimony under the Frye standard. See, e.g., In re Paoli R.R. Yard PCB Litig., 35 F.3d 717 (3d Cir. 1994); United States v. Jones, 24 F.3d 1177 (9th Cir. 1994) (affirming exclusion of expert testimony concerning voice identification); O'Conner v. Commonwealth Edison Co., 13 F.3d 1090 (7th Cir. 1994) (affirming exclusion of expert testimony that plaintiff's cataracts were caused by a radiation dose thousands of times less than that commonly believed by experts to be required to cause this condition); Amorgianos v. Nat'1 R.R. Passenger Corp., 137 F. Supp. 2d 147, 163 (E.D.N.Y. 2001). Some courts not following the Federal Rules of Evidence have declined to apply a Daubert-type analysis, instead opting for the more restrictive Kelly/Frye general acceptance test. See, e.g., State v. Coon, 974 P.2d 386, 395 (Alaska 1999); People v. Leahy, 882 P.2d 321, 337 (Cal. 1994).

45. Daubert, 509 U.S. at 600 (Rehnquist, C.J., concurring in part and dissenting in part). The confusion surrounding Daubert has spawned multiple web sites. See, e.g., Daubert Tracker, http:// www.dauberttracker.com (last visited Mar. 22, 2008); Stephen Mahle, DaubertExpert.com, http:// www.daubertexpert.com (last visited Mar. 22, 2008); Peter Nordberg, Daubert on the Web, http:// www.daubertontheweb.com (last visited Mar. 22, 2008).

46. See, e.g., Edward K. Cheng \& Albert H. Yoon, Does Frye or Daubert Matter? A Study of Scientific Admissibility Standards, 91 VA. L. REv. 471 (2005); Lloyd Dixon \& Brian Gill, Changes in the Standards for Admitting Expert Evidence in Federal Civil Cases Since the Daubert Decision, 8 Psychol. Pub. Pol'y \& L. 251 (2002); Lynn R. Johnson et al., Deciphering Daubert, Trial, Nov. 1997, at 71.

47. See, e.g., Weisgram v. Marley Co., 528 U.S. 440, $455-456$ (2000); United States. v. Scheffer, 523 U.S. 303 (1998); Tome v. United States 513 U.S. 150, 174-75 (1995).

48. Daubert, 509 U.S. at 580.

49. Id. at 593 . 
be derived by the scientific method." ${ }^{50}$ In order to determine whether proffered evidence is "scientific knowledge" that "will assist the trier of fact [usually the jury] to understand or determine a fact in issue," the majority provided a list of criteria (Daubert criteria) to assist the trial judge's assessment:

(1) whether the expert's theory can be or has been tested; (2) whether the theory has been subject to peer review and publication; (3) the known or potential rate of error of a technique or theory when applied; (4) the existence and maintenance of standards and controls; and (5) the degree to which the technique or theory has been generally accepted in the scientific community. ${ }^{51}$

Generally, the Daubert criteria have been reduced to four criteria (combining two of the above): (1) whether the methods upon which the testimony is based are centered upon a testable hypothesis; (2) the known or potential rate of error associated with the method; (3) whether the method has been subject to peer review; and (4) whether the method is generally accepted in the relevant scientific community. ${ }^{52}$ Notwithstanding the provision of specific criteria, the majority in Daubert explained that any inquiry under Rule 702 should be "flexible." 53 In consequence, the factors were characterized as indicative rather than as a "definitive checklist or test." ${ }^{54}$

\section{E. Does Daubert Undermine the Seventh Amendment?}

Although the purported goal of Daubert is to liberalize the admissibility of expert evidence, it also deputizes federal judges as amateur scientist gatekeepers. Justice Rehnquist, who concurred and dissented in part, questioned this aspect of the Court's holding: "I do not doubt that Rule 702 confides to the judge some gatekeeping responsibility in deciding questions of the admissibility of proffered expert testimony. But I do not think it imposes on them either the obligation or the authority to become amateur scientists in order to perform that role." ${ }^{, 5}$ In their role as amateur scientists, judges examine a theory, gather opposing facts about it, and then attempt to 593-95).

50. Id. at 589-90.

51. Moore v. Ashland Chem. Inc., 151 F.3d 269, 275 (5th Cir. 1998) (citing Daubert, 509 U.S. at

52. Kumho Tire Co., Ltd. v. Carmichael, 526 U.S. 137, 141 (1999) (noting that Daubert discussed four factors - testing, peer review, error rates, and "acceptability" in the relevant scientific community).

53. Daubert, 509 U.S. at 594.

54. Id. at 593 .

55. Id. at 600-01 (Rehnquist, C.J., concurring in part and dissenting in part). 
make a "reasoned judgment" about which set of facts are correct. Traditionally, this has been a role for American juries, not judges. ${ }^{56}$ In this sense Daubert might very well be said to undermine the Seventh Amendment's right to a jury trial.

The Seventh Amendment to the United States Constitution states:

\begin{abstract}
In Suits at common law, where the value in controversy shall exceed twenty dollars, the right of trial by jury shall be preserved, and no fact tried by a jury, shall be otherwise re-examined in any Court of the United States, than according to the rules of the common law. ${ }^{57}$
\end{abstract}

According to case law, an issue is submitted to the jury if reasonable people might differ on the conclusions to be reached based on the evidence. ${ }^{58}$ Courts have also maintained that it is not the role of the judge to determine facts for the jury. ${ }^{59}$ Expert opinion, when based on facts that sustain it, ought to have the force of a fact at the trial level. ${ }^{60}$ Thus it would seem that the American judiciary has embraced the notion that the Seventh Amendment includes the right to have one's expert testimony heard by a jury. However, the judge acting as a gatekeeper at a Daubert hearing (where he is acting in the role of a juror) is essentially blocking a litigant's right to a jury trial.

\title{
IV. Daubert's Evolution: The Companion Cases
}

Two cases further refined the Supreme Court's Daubert analysis: General Electric Co. v. Joiner ${ }^{61}$ in 1997 and Kumho Tire Co. v. Carmichael ${ }^{62}$ in 1999. In these cases, the Court seems to have backed away from its analysis of Daubert as liberalizing the admittance of evidence. As Justice Rehnquist, who earlier worried in his Daubert dissent about abuse of this power by district court judges, writes in Joiner, "[t]hus, while the Federal Rules of Evidence allow district courts to admit a somewhat broader range of scientific

56. See Allan Kanner, Ruminations on Trial by Jury: An Essay in Honor of Judge Robert S. Vance (pts. 1 \& 2), 5 Toxic L. Rep. (BNA) 415 (1990).

57. U.S. Const. amend. VII; see also Raytheon Mfg. Co. v. RCA, 76 F.2d 943, 947 (1st Cir. 1935) (holding that neither Congress nor the courts can deprive a litigant of his right to a trial by jury).

58. Helene Curtis Indus., Inc. v. Pruitt, 385 F.2d 841, 850 (5th Cir. 1967) (affirming that the Fifth Circuit employs this test when determining whether an issue should be submitted to the jury).

59. Garcia v. Murphy Pac. Marine Salvaging Co., 476 F.2d 303, 306 (5th Cir. 1973).

60. Galloway v. United States, 319 U.S. 372, 396 (1943).

61. 522 U.S. 136 (1997).

62. 526 U.S. 137 (1999). 
testimony than would have been admissible under Frye, they leave in place the 'gatekeeper' role of the trial judge in screening such evidence." ${ }^{\prime 63}$

\section{A. General Electric Co. v. Joiner}

Joiner involved the proper standard of review for an appellate court looking at a district court's ruling on a Daubert motion. The Court held that the notion "that abuse of discretion is the proper standard of review of a district court's evidentiary rulings" also applies to Daubert rulings. ${ }^{64}$ The Court also acknowledged that "[c] ]ases arise where it is very much a matter of discretion with the court whether to receive or exclude the evidence." ${ }^{95}$ Despite the concession that discretionary judges can sink or float cases at will, the Court maintained that such discretionary decisions should only be overturned if "manifestly erroneous." ${ }^{" 66}$ As a result, the Supreme Court has effectively empowered district court judges with the authority to avoid trying a case on the merits. As will be discussed below, the results of this grant of power have been disastrous for the civil justice system. Ultimately, if a district court judge does not want to try a case, he or she can find a way to avoid doing so.

\section{B. Kuhmo Tire Co. v. Carmichael}

The Court next addressed the extent of Daubert's gatekeeper role. In Kumho Tire, the Court held that this role extended not only to scientific testimony but also to all expert testimony. ${ }^{67}$ This includes such fields as engineering or those that involve "other specialized" knowledge." ${ }^{98}$ The Court ruled that the Daubert criteria, while originally established for scientific evidence, could be used to evaluate other types of expertise and that "Daubert's fundamental holding, that an expert's testimony must be both relevant and reliable, applies to all experts." ${ }^{69}$ Since the case was decided, courts continue to apply Daubert factors in situations of which the majority in Kuhmo Tire probably never conceived. The following expert testimony has

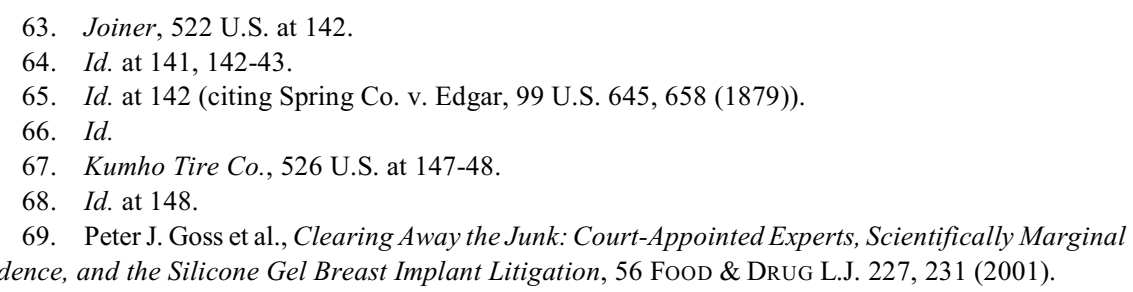


faced Daubert challenges in certain cases: testimony by an appraiser, ${ }^{70}$ an expert in police procedures, ${ }^{71}$ an engineer, ${ }^{72}$ a lawyer testifying about attorney's fees, ${ }^{73}$ a helicopter pilot, ${ }^{74}$ a helicopter mechanic, ${ }^{75}$ an economist,${ }^{76}$ an accountant, ${ }^{77}$ and a police officer (as an expert in drug trafficking). ${ }^{78}$

\title{
C. The Federal Rules of Evidence
}

The drafters of the Federal Rules of Evidence amended Rule 702 in 2000 to conform to, or enrich, the Supreme Court's definition in Daubert of the district court's inquiry:

\begin{abstract}
If scientific, technical or other specialized knowledge will assist the trier of fact to understand the evidence or to determine a fact in issue, a witness qualified as an expert by knowledge, skill, experience, training, or education, may testify thereto in the form of an opinion or otherwise, if (1) the testimony is based upon sufficient facts or data, (2) the testimony is the product of reliable principles and methods, and (3) the witness has applied the principles and methods reliably to the facts of the case. $^{79}$
\end{abstract}

The trial court will then attempt to understand and critically evaluate the expert's scientific or technical methodology, even when that evaluation determines the outcome of a case. The federal trial courts are thus assigned a substantial task, well beyond the parameters of the general acceptance test of Frye: validation of the scientific technique that the expert employs in both its broader application and its case-specific use.

\section{Later Case Law}

Since the Daubert/Joiner/Kuhmo Tire trilogy and the modification of Rule 702, the Supreme Court has been conservative in upholding the

70. Abramson v. Fla. Gas Transmission Co., 909 F. Supp. 410, 419-20 \& n.18 (E.D. La. 1995).

71. Berry v. City of Detroit, 25 F.3d 1342, 1350-51 (6th Cir. 1994).

72. Brown v. Miska, No. CIV. A. V-94-067, 1995 WL 723156, at *2, *4 (S.D. Tex. July 19, 1995).

73. Evans v. Phila. Hous. Auth., Civ. A. No. 93-5547, 1995 WL 154872, at *3, *6 (E.D. Pa. Mar. 31, 1995), aff'd, 79 F.3d 1139 (3d Cir. 1996).

74. Frosty v. Textron, Inc., 891 F. Supp. 551, 553 (D. Or. 1995).

75. Id.

76. In re Aluminum Phosphide Antitrust Litig., 893 F. Supp. 1497, 1499-1500 (D. Kan. 1995).

77. Morse/Diesel, Inc. v. Trinity Indus., Inc., 67 F.3d 435, 444 (2d Cir. 1995).

78. United States v. Thomas, 74 F.3d 676, 680 (6th Cir. 1996).

79. FED. R. EvID. 702. 
admission of expert witness testimony. In Weisgram v. Marley Co. ${ }^{80}$ the Court resolved a circuit split regarding Federal Rule of Civil Procedure 50 (Judgment as a Matter of Law). The Supreme Court held that Rule 50 permits an appellate court to direct the entry of judgment as a matter of law if it determines that evidence was erroneously admitted at trial and that the remaining, properly admitted evidence is insufficient to constitute a triable case.$^{81}$ A court of appeals may therefore throw out expert testimony, find remaining evidence insufficient, and proceed to grant a judgment notwithstanding the verdict. The Court rejected the plaintiff's argument for an "automatic remand." ${ }^{\prime 2}$ It focused on the fact that Daubert has put litigants on notice: "It is implausible to suggest, post-Daubert, that parties will initially present less than their best expert evidence in the expectation of a second chance should their first try fail." ${ }^{83}$ Since Daubert, plaintiffs have notice of the "exacting standards of reliability." 84

Appellate courts, however, have not exercised this power. The Eleventh Circuit in Toole v. Baxter Healthcare Corp.${ }^{85}$ noted, "We review a trial court's evidentiary rulings on the admission of expert witness testimony for abuse of discretion." ${ }^{" 86}$ Moreover, some appellate courts have been lenient as to when Daubert applies and how closely it should be followed. One court found that there is no requirement that a district court always hold a Daubert hearing prior to qualifying an expert witness under Federal Rule of Evidence 702. ${ }^{87}$ Rule 702 "permits a district court to allow the testimony of a witness whose knowledge, skill, training, experience or education will assist a trier of fact in understanding an area involving specialized subject matter." ${ }^{88}$ Courts conform to the Daubert factors to differing degrees. The Third Circuit in Fillebrown v. Steelcase, Inc. ${ }^{89}$ stated, "[T] he Daubert test for reliability is flexible and

80. 528 U.S. $440(2000)$.

81. Id. at $447-56$.

82. Id.

83. Id. at 455 .

84. $I d$.

85. 235 F.3d 1307 (11th Cir. 2000).

86. Id. at 1312 (citations omitted).

87. United States v. Solorio-Tafolla, 324 F.3d 964, 965 (8th Cir. 2003) (quoting United States v. Evans, 272 F.3d 1069, 1094 (8th Cir. 2001)).

88. Solorio-Tafolla, 324 F.3d at 966 (quoting United States v. Molina, 172 F.3d 1048, 1056 (8th Cir. 1999)); cf. United States v. Alatorre, 222 F.3d 1098 (9th Cir. 2000) (upholding admission of expert testimony by district court which was to assist with complex matters).

89. 63 F. App'x 54 (3d Cir. 2003). 
'Daubert's list of specific factors neither necessarily nor exclusively applies to all experts or in every case.","90

\section{Corporate Influence in Science: The “Junk Science” Revolution}

Once thought of as a domain where policy-makers might go for objective research, much science today is dominated more by a desire to protect industry than arrive at the truth. In short, science is in play. And no group is playing harder than corporations who must answer with money damages when scientists label their products as dangerous.

For the decades before Daubert, a new consciousness among Americans regarding environmental and product safety led to an increase in such suits. The asbestos lawsuits raised many industry fears regarding the extent of their own liability. Industry responded by trying to influence public policy and close the courts to injured parties. The Manhattan Institute, a corporatefunded think tank, working with pro-industry activist Peter Huber, began a blitzkrieg campaign to promote the phrase "junk science." As a backdrop to this campaign was Huber's widely-read book, Galileo's Revenge. ${ }^{91}$ Huber's definition of junk-science leaves open plenty of room for interpretation:

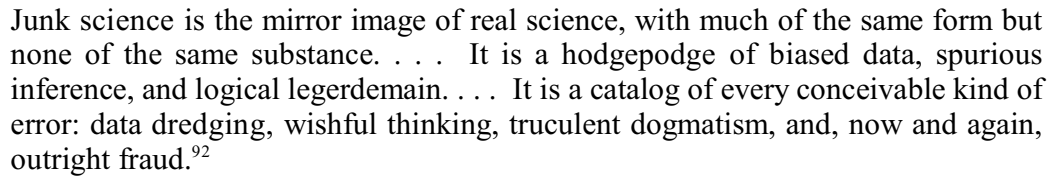

In other words, "junk science" is any science that the beholder (or judge) does not agree with. Any science that goes against one's preconceived notions about which products are safe and which are not can conceivably meet this definition. Industry think tanks invented a new label for pro-industry judges to affix to plaintiffs with whom they personally disagreed.

Huber's influence cannot be understated. Ninth Circuit Court of Appeals Justice Alex Kozinski used Huber's conception of good science in the preremanded Daubert decision. Kozinski wrote that case law "reflect[s] a wellfounded skepticism of the scientific value of the reanalysis methodology employed by plaintiffs' experts; they recognize that ' $[t]$ he best test of certainty we have is good science - the science of publication, replication, and

90. Id. at 56 (citing Kumho Tire, 526 U.S. at 142).

91. Peter W. Huber, Galileo's Revenge: Junk Science in the Courtroom (1991).

92. Id. at 2-3. 
verification, the science of consensus and peer review." continually infiltrates the ranks of science and medicine. Industry funding of university science departments has climbed significantly in recent years. ${ }^{94}$ Gifts from industry to drug-prescribing physicians are now the norm. ${ }^{95}$ The tobacco industry has hired actors with science degrees to change public opinion on second-hand smoke. ${ }^{96}$ Scientists even feel pressured regarding the subject matter of their research. ${ }^{97}$

There is a battle underway for the soul of science. On the one hand are objective researchers. Environmental and social groups do not have the financial resources to fund their own research to meet their ideological needs. And opposed to objective research are the industry scientists, whose allegiance lies with their corporate backers, rather than the truth. Generally, a jury will be able to determine the motivations of each side. But there are some pro-industry members of the judiciary who, armed with Daubert, are making sure the jury never has that opportunity.

\section{The Judiciary Today and the Abuse of DaUberT}

It is easy, by very ingenious and astute construction, to evade the force of almost any statute, where a court is so disposed.

— Justice Grier ${ }^{98}$

[I]t is never the Law itself that is in the wrong: it is always some wicked interpreter of the Law that has corrupted and abused it.

- Jeremy Bentham ${ }^{99}$

The combination of motive and opportunity is dangerous, especially when judges have incentives to prevent a litigant from enjoying his right to a jury trial. The incentives for judges to dismiss cases are borne from increasing

93. Daubert v. Merrell Dow Pharm., Inc., 951 F.2d 1128, 1131 (9th Cir. 1991), vacated, 509 U.S. 579 (1993) (quoting HuBER, supra note 91, at 228).

94. Henry Etzkowitz, The Norms of Entrepreneurial Science: Cognitive Effects of the New University-Industry Linkages, 27 RESEARCH POL'y 823 (1998).

95. See Jason Dana, A Social Science Perspective of Gifts to Physicians from Industry, 290 J. AM. MED. Ass'N 252 (2003), available at http://jama.ama-assn.org/cgi/content/full/290/2/252 (subscription required).

96. See Monique E. Muggli et al., Science for Hire: A Tobacco Industry Strategy to Influence Public Opinion on Secondhand Smoke, 5 Nicotine \& Tobacco Research 303 (2003).

97. See Waverly W. Ding, Does Science Chase Money? (2006) (on file with University of Pittsburgh Law Review).

98. Pillow v. Roberts, 54 U.S. 472, 475 (1851).

99. Jeremy Bentham, Fragment on Government 11 (Harrison Wilfred ed., The Macmillan Co. 1948) (1776). 
caseloads, insufficient trial experience, the duty to "manage" cases, and a bias toward industry. Daubert gives a powerful tool to judges with incentives to dismiss.

Two of the favorite tools of managerial judges (and in some cases their law clerks) are summary judgments ${ }^{100}$ and Daubert challenges to scientific or technical proof. ${ }^{101}$ If a court is unwilling or unable to try cases, Daubert certainly can be abused. ${ }^{102}$ The opportunity to dismiss a case which should be heard by a jury is within every judge's grasp.

100. Federal Rule of Civil Procedure 56(c) provides that summary judgment is appropriate "if the pleadings, the discovery and disclosure materials on file, and any affidavits show that there is no genuine issue as to any material fact and that the movant is entitled to judgment as a matter of law." An issue is "genuine" only if there is a sufficient evidentiary basis on which a reasonable jury could find for the nonmoving party. Anderson v. Liberty Lobby, Inc., 477 U.S. 242, 249 (1986). A factual dispute is "material" only if it might affect the outcome of the suit under governing law. Id. at 248. And, all inferences must be drawn, and all doubts resolved, in favor of the non-moving party. United States v. Diebold, Inc., 369 U.S. 654, 655 (1962); Gans v. Mundy, 762 F.2d 338, 341 (3d Cir. 1985). On a motion for summary judgment, the moving party bears the initial burden of identifying for the court those portions of the record that it believes demonstrate the absence of dispute as to any material fact. Celotex Corp. v. Catrett, 477 U.S. 317, 323 (1986). To defeat summary judgment, the non-moving party may not rest upon the mere "allegations or denials in its own pleading; rather, its response must—-by affidavits or as otherwise provided in this rule-set out specific facts showing a genuine issue for trial." FED. R. CIV. P. 56(e). The nonmoving party must demonstrate the existence of evidence that would support a jury finding in its favor. See Anderson, 477 U.S. at 248-49.

101. Additional aspects of this phenomenon include the ever increasing contraction of discovery rights through rulings and court rule amendments. For the past fifteen years, the ability of requesting parties to use the broad discovery rights originally envisioned in the Federal Rules of Civil Procedure, and the notice-pleading regime they complement, has been steadily curtailed:

- the right to obtain information through lawyer-managed discovery, not through mandatory, limited disclosure requirements

- the right to determine how many interrogatories and depositions are necessary to develop adequate proof

- the right to depose a witness for as long as it takes to get answers to relevant questions

- the right to get all relevant information, not merely what the opposing party decides is supportive of claims and defenses

- the right to complete discovery without repeated hearings before judges or discovery masters, with the attendant cost in time and money.

From a legislative point of view, industry is now targeting special treatment for-and limitations on-electronic discovery. The ABA Litigation Section is also developing standards. See ABA, Electronic Discovery, http://www.abanet.org/litigation/issuecenter/issue_ediscovery.html (last visited Mar. 22, 2008).

102. See Eleanor Swift, One Hundred Years of Evidence Law Reform: Thayer's Triumph, 88 CAL. L. REv. 2437, 2466-68 (2000). 


\section{A. The Incentive to Prevent Jury Trials}

Judges today are faced with more and more incentives to prevent cases from going to trial. Budget cuts have led to increasing caseloads which have made "docket cleaning" the obsession of many judges. Furthermore, more judges are coming to the bench with less trial experience, and thus attempt to steer parties away from trial. The concept of the "managerial judge" is gaining acceptance in jurisprudence circles (wherein the judge takes active steps to steer parties away from trial as part of his or her position). And finally, some judges hold pro-business biases (or, more tactfully, they believe juries hold anti-business biases). All of these pressures need to be understood in order to appreciate how they combine to produce bad law, including the misapplication of Daubert. For example, an aversion to jury trials has led to improperly expansive interpretations of the Federal Arbitration Act. ${ }^{103}$ Again, an aversion to class action trials has contributed to the approval of bad class settlements. ${ }^{104}$

\section{Increasing Caseloads}

Federal judges in many districts are burdened with an impossible caseload, especially because of their criminal dockets. ${ }^{105}$ This situation continues to worsen. Congress routinely increases this workload by adding new federal claims. ${ }^{106}$ The Class Action Fairness Act, for example, will increase the federal judiciary workload. ${ }^{107}$ At the same time, Congress refuses

103. 9 U.S.C. $\S \S 1-14$ (2000); see William G. Young, An Open Letter to U.S. District Judges, FeD. LAW., July 2003, at 30, 33 .

104. Allan Kanner \& Tibor Nagy, Exploding the Blackmail Myth: A New Perspective on Class Action Settlements, 57 BAYLor L. ReV. 681, 699-700 (2005).

105. However, the notion of a national crisis resulting from a litigation explosion is not well-grounded in empirical science. See, e.g., William Haltom \& Michael McCann, Distorting the Law: Politics, Media, And the Litigation Crisis (2004) (arguing that the perception of the United States as overwhelmed by litigation and in desperate need of tort reform is empirically false yet still constitutes popular knowledge of law).

106. For example, between 1970 and 1998 the number of federal criminal statutes nearly doubled to 3,000, according to a 1998 American Bar Association study. TASK ForCE ON THE FEDERALIZATION OF Criminal Law, Am. Bar Ass'n, The Federalization of Criminal Law 9-11 \& app. c (1998).

107. The Federal Judicial Conference, previously led by former Chief Justice Rehnquist, opposes the "Class Action Fairness Act" because "of concerns that the provisions would add substantially to the work load of the federal courts and are inconsistent with principles of federalism." Letter from the Federal Judicial Conference to Senator Orrin Hatch, Chairman of the Senate Judiciary Comm. (Mar. 26, 2003). 
to budget adequate monies for federal courts and their attendant bureaucracies, ${ }^{108}$ which is leading to crisis situations in many circuits. ${ }^{109}$

The pressure on judges to "clear their dockets" has never been greater. ${ }^{110}$ This is probably more likely due to budget cuts than any actual litigation explosion. ${ }^{11}$ Also, the arrival of some high profile mass-tort cases have some judges fearing the worst. As one commentator noted, "The asbestos, Agent Orange, Dalkon Shield, and breast implant litigations were all national events, covered by the media, [and] watched by other judges concerned about their own dockets." $" 12$

\section{Inexperienced Trial Judges}

[T] he judge should not be young; he should have learned to know evil, not from his own soul, but from late and long observation of the nature of evil in others: knowledge should be his guide, not personal experience.

- Plato $^{113}$

Some district judges are appointed without sufficient consideration of the adequacy of their civil trial experience. Without a minimum of trial experience, many judges seek to avoid trials. In addition, they risk developing biases in the handling of cases that play to their strengths and avoid their weaknesses. This usually means resolution (forced mediation, for example) without trial.

Generally, members of Congress recommend potential nominees as district court judges. The President then nominates the judge. After confirmation hearings by the Senate Judiciary Committee, and absent a

108. James Morgan, ABA Urges Congress to Fund Federal Judiciary, Litig. News, Jan. 2005 at 5 (stating that a budget crisis threatens access to justice); see also Tom Schoenberg, Federal Courts Avert Budget Disaster, Legal Times, Nov. 29, 2004, at 3. There are non-monetary fixes that could lessen some of these budgetary demands, especially in the area of GSA charges.

109. A letter from the Leadership Conference on Civil Rights to the Senate, Mar. 20, 2003, states that

S. 247 is an unnecessary attempt to impose federal judicial regulation on matters of law clearly committed to the states .... [T] he imposition of such substantial new responsibilities on the

federal courts will further impair the ability of those courts to carry out essential functions they are intended to serve under the Constitution.

110. For an in-depth discussion of this matter, see John C. Coffee, Jr., Class Wars: The Dilemma of the Mass Tort Class Action, 95 Colum. L. Rev. 1343 (1995).

111. See, e.g., William Mears, Rehnquist Calls for Full Funding of Federal Courts, CNN News, Jan. 2, 2003, http://www.cnn.com/2003/LAW/01/02/rehnquist.judges/index.html (last visited Mar. 22, 2008).

112. Coffee, supra note 110 , at 1410.

113. Plato, The Republic 95 (Benjamin Jowett trans., The Modern Library, 1941). 
filibuster, a simple Senate majority approves the nominees. Advising the President during this nomination process is the American Bar Association Standing Committee on the Federal Judiciary (Standing Committee). ${ }^{14}$ The group was ostensibly created because there are no statutory or constitutional qualifications for any federal judge - they need not even have a law degree. ${ }^{115}$ The group does not consider a nominee's philosophy or ideology, only his or her professional qualifications: integrity, professional competence, and judicial temperament. ${ }^{116}$ The Standing Committee explains these in more detail:

When the Committee evaluates "integrity," it considers the nominee's character and general reputation in the legal community, as well as the nominee's industry and diligence.

"Professional competence" encompasses such qualities as intellectual capacity, judgment, writing and analytical abilities, knowledge of the law, and breadth of professional experience.

In evaluating "judicial temperament," the Committee considers the nominee's compassion, decisiveness, open-mindedness, courtesy, patience, freedom from bias, and commitment to equal justice under the law. ${ }^{17}$

Apparently, the current emphasis by the legislative and executive branches on the ideology of judges has diminished the importance of a judicial nominee's professional qualifications. Since 1952, the Standing Committee was consulted by every President, Republican and Democrat, prior to a judge's nomination to the bench. ${ }^{118}$ This half-century bipartisan emphasis on experience was abruptly ended by the Bush Administration, which announced in 2001 that it would no longer notify the Standing Committee of the identity of its nominees prior to their nomination. ${ }^{119}$ This effectively means that the Bush Administration does not seek the impartial opinion of the American Bar Association before nominating a person as a federal judge.

This change in stance has led to a less-qualified judiciary. While the Standing Committee found only four candidates to be unqualified in the twelve years preceding the Bush Administration, six candidates have already

114. Am. Bar Ass'n, The ABA Standing Committee on the Federal Judiciary: What It Is and How It WORKs 1 n.1 (2007), available at http://www.abanet.org/scfedjud/federal_judiciary07.pdf [hereinafter ABA Standing Committee on Federal Judiciary].

115. See U.S. Const. art. III, $\S 1$.

116. ABA Standing Committee on Federal Judiciary, supra note 114, at 2.

117. Id. at 3-4.

118. Id. at $1 \mathrm{n} .1$.

119. Id. 
been determined to be unqualified since 2001. ${ }^{120}$ This trend represents a weakening of the notion that a judge ought to possess greater qualifications than a certain ideological bent. For example, one of the nominees receiving a "qualified" to "not-qualified" rating by the ABA in 2005 was William Myers, a nominee for the Ninth Circuit Court of Appeals. ${ }^{121}$ Myers has never been a judge at any level, has never been a law professor, and has never participated in a jury trial. ${ }^{122}$ Judges without academic or trial experience are going to avoid jury trials at all costs (and defer to the trial court's Daubert assessment at the appeals level) so as not to reveal their weaknesses.

\section{The Judge as Manager}

The culture of federal judging has also undeniably moved towards the ideal of the managerial judge and away from the more neutral judicial umpire in the trial model. ${ }^{123}$ Under this approach, judges attempt to expedite the process or bring about closure rather than provide an passive forum for the parties to settle a dispute. ${ }^{124}$ This is a significant trend. ${ }^{125}$

120. For the Committee ratings of all federal judicial nominess of the 107th-110th Congresses, see Am. Bar Ass'n, ABA Standing Committee on the Federal Judiciary, Ratings for Judicial Nominees, http://www.abanet.org/scfedjud/ratings.html (last visited Mar. 22, 2008).

121. Am. Bar Ass'n, Ratings of Article III Judicial Nominees: 109th Congress, http:// www.abanet.org/scfedjud/ratings/ratings 109.pdf (last visisted Mar. 22, 2008).

122. Editorial, A Hostile Judge, The Boston Globe, Mar. 22, 2004, at A10, available at 2004 WLNR 3585701.

123. See generally Judith Resnik, Managerial Judges, 96 HARv. L. Rev. 374 (1982).

124. The Federal Judicial Center, basing itself on comments received from many judges, lawyers and academics, has described effective management as generally having the following characteristics:

It is active. The judge attempts to anticipate problems before they arise rather than waiting passively for matters to be presented by counsel. Because the attorneys may become immersed in the details of the case, innovation and creativity in formulating a litigation plan may frequently depend on the court.

It is substantive. The judge's involvement is not limited to procedural matters. Rather, the judge becomes familiar at an early stage with the substantive issues in order to make informed rulings on issue definition and narrowing, and on related matters, such as scheduling, bifurcation and consolidation, and discovery control.

....

It is continuing. The judge periodically monitors the progress of the litigation to see that schedules are being followed and to consider necessary modifications of the litigation plan. The judge may call for interim reports between scheduled conferences.

It is firm, but fair. Time limits and other controls and requirements are not imposed arbitrarily or without considering the views of counsel, and they are subject to revision when warranted by the circumstances. Once having established a program, however, the judge expects schedules to be met and, when necessary, imposes appropriate sanctions . . . for derelictions and dilatory tactics. 


\section{Professor McGovern explained this shift:}

What's happening on the judicial side? When most of us went to law school, the judge was viewed as an umpire, calling the balls and strikes. As far as the lawyers, the adversarial system - it wasn't very inquisitorial.

Then with the judicial management school, the Federal Judicial Center, and its baby judges' conferences, we saw the role of the judge shift from umpire to manager. The job of the judge is to manage litigation. Some of us have made the argument that it's morphed even further, into the judge as player. When a judge aggregates huge numbers of cases in one particular forum to leverage a settlement, he is just as much a player as the attorneys.

In Multi-District Litigation, or MDL, judges originally were umpires. Their job was just to decide the pretrial discovery and to send the cases back for trial. In the Dalkon Shield case, that's what happened.

When Jack Weinstein resolved Agent Orange, and as the managerial judging movement progressed, what we saw was a different model in the eyes of the federal MDL judges. Their role was to resolve the entire litigation without having to send it back. So we saw Judge Bechtel resolving any number of cases, most recently FenPhen, for example; that was the role of the federal judge. ${ }^{126}$

While a managerial approach makes sense in some circumstances, it is neither sensible nor appropriate in all cases. ${ }^{127}$ Indeed, it has reached the point where many federal judges view a trial as some sort of failing on their part.

Federal Judicial Center, Manual for Complex Litigation (Third) § 20.13 (1995).

125. Active case management is a process which is being applied in many jurisdictions, even outside the United States. Professor Sallmann of the Australian Institute of Judicial Administration has summarized the "quiet but enormously significant revolution" that has already occurred in the Higher Courts of Australia in this way:

The revolution has involved a dramatic shift from a laissez faire approach in conducting court business to an acceptance by courts of the philosophical principle that it is their responsibility to take an interest in cases from a much earlier stage in the process and to manage them through a series of milestones to check points. Most courts have now acted upon this philosophy and introduced a variety of schemes, the common denominator of which is substantially increased court supervision and, in some instances, control. Broadly speaking activity has occurred under the banner of "case flow management." The concept means different things to different people. The essence of it is the adoption by courts of a systematic, managerial approach to dealing with case loads.

Access to Justice Advisory Comm., Access to Justice: An Action Plan, ch. 5 , at 9 (1994).

126. Professor Francis McGovern, Deceptive Trade Practices Litigation: Context and Procedural Standards, Speech at the Center for Legal Policy at the Manhattan Institute Conference (Oct. 24, 2002), in Unfair Competition and Consumer Fraud Statutes: Recipe for Consumer Fraud Prevention or Fraud ON THE CONSUMER 18 (2002), available at http://www.manhattan-institute.org/pdf/mics9.pdf.

127. Some negative consequences of putting efficient management before fairness are welldocumented. See generally Victor E. Schwartz \& Leah Lorber, A Letter to the Nation's Trial Judges: How The Focus on Efficiency is Hurting You and Innocent Victims in Asbestos Liability Cases, 24 Am. J. TRIAL Advoc. 247 (2000); Francis E. McGovern, The Defensive Use of Federal Class Actions in Mass Torts, 39 ARIz. L. ReV. 595 (1997). 
For attorneys representing harmed clients, this attitude should be a matter of great concern. ${ }^{128}$ More troubling, what some judges mean by "management" is simply wearing the parties down until they settle. This strategy does little to advance the goals of fairness or efficiency in resolving the underlying dispute.

\section{The Pro-Business Judge}

It is unrealistic to claim that no judges hold a pro-industry bias. The bitter legislative fights over federal judge appointments demonstrate the rift in the judiciary. Such judges understand that jury trials present great risks to corporate defendants, and they may not trust juries to judge the defendant fairly. ${ }^{129}$ The refusal of the Bush Administration to subject their potential nominees to ABA screening has only enflamed the problem of biased judges. Consider again the example of the unqualified William Myers. One of the reasons Myers received such a low ABA rating was that he has essentially been a corporate lobbyist for the mining and cattle industries for most of his career, and his legal reasoning ability is seriously in doubt. ${ }^{130}$ Myers's industry bias (which spurns Supreme Court precedent) is easy to ascertain:

He has compared federal management of public lands to "the tyrannical actions of King George in levying taxes" on the Colonies without their representation. He considers both the Endangered Species Act and the Clean Water Act's wetlands protections to be examples of "regulatory excesses" and has argued that private property rights are as fundamental as free speech rights. This is a view, repeatedly rejected by the US Supreme Court, that would undercut a wide spectrum of zoning and environmental laws. ${ }^{131}$

128. In addition, the managerial judge is also too much of an administrator. The most important metrics for a district judge are how long motions sit. Given their fixed salary, judges do not earn any more money for trying cases. Like an assembly line worker on a fixed salary, where is the incentive to "produce" more?

129. Critics of the jury system often point to Peter W. Huber, Liability: The Legal Revolution AND ITS CONSEQUENCES 14 (1988), including the petitioners in their Kumho Tire brief. Most of Huber's conclusions regarding the inability of the jury to comprehend scientific evidence were refuted by other research, most notably Edward J. Imwinkelried, The Standard for Admitting Scientific Evidence: A Critique from the Perspective of Juror Psychology, 28 VILL. L. REv. 554 (1983), and Neil Vidmar, Pap and Circumstance: What Jury Verdict Statistics Can Tell Us About Jury Behavior and the Tort System, 28 Suffolk U. L. ReV. 1205 (1994).

130. A Hostile Judge, supra note 122 , at A10.

131. $I d$. 
The pro-industry Chamber of Commerce also has recognized the importance of stacking the judiciary with biased judges, and has been more involved than ever in the election of state judges. ${ }^{132}$ The Chamber has also been more active regarding the selection of federal judges. ${ }^{133}$

\section{Loss of Focus}

U.S. District Court Judge William Young argues that the reason the jury trial is dying in federal courts is that "we [district court judges] have lost focus on our prime mission; our status as the grassroots guardians of constitutional values is threatened as never before." 134 Judge Young noted the twenty-six percent decline of civil jury trials and contended that an unfocused federal judiciary "has been willing 'to accept a diminished, less representative, and thus sharply less effective civil jury.",135 According to Young,

Ours is a dual mission. First, we preside over the largest, most daring, and most successful experiment in direct democracy ever attempted in the history of the world - the American jury system. The continued vitality of that system depends, in no small measure, on the skillful management and warm inspirational support of U.S. District Court judges.

Second, alone among the democracies of the world, we commit first-instance constitutional interpretation to U.S. district judges. In contrast, most countries reserve constitutional adjudication for a special appellate court. The result is plain - the U.S. Constitution is the most vibrantly living written governmental framework and guarantee of individual liberties ever seen-precisely because reasoned, case specific, written interpretation of the fundamental law is as close as the nearest federal district court. ${ }^{136}$

Federal judges, even those unbiased against litigation, are losing focus of their mission to encourage and support the jury system.

132. See, e.g., Associated Press, Supreme Court Won't Weigh in on Chamber of Commerce Election $A d s$, First Amendment Ctr. News, May 29, 2001, http://www.firstamendmentcenter.org/news.aspx?id= 5025 (last visited Mar. 22, 2008) (stating that the Chamber, restricted in its donating to judicial candidates, nonetheless ran "issue ads" supportive of candidates considered pro-business).

133. See, e.g., Institute for Legal Reform, About ILR, http://www.instituteforlegalreform.org/about/ index.cfm (last visited Mar. 22, 2008).

134. Young, supra note 103, at 30.

135. Id. at 31 (quoting Ciulla v. Rigny, 89 F. Supp. 2d 97, 102 n.6 (D. Mass. 2000) (internal citations omitted)).

136. Id. at 32 . 


\section{B. Daubert: The Opportunity to Prevent Jury Trials}

Judges, having many incentives to prevent a case from going to trial, also possess the opportunity to do so. Daubert, with its many criteria, allows a judge to focus on just one criteria, weigh it unevenly, and use it to prevent expert testimony (in many cases central to a plaintiff's entire case) from reaching the courtroom. And Joiner gives the judge peace of mind that his ruling, however unreasonable, will probably not be overturned on appeal.

Daubert motions present a tempting opportunity for judges to dispose of cases without risk of appellate review. As Professor McGarity stated: "After more than a decade of experience with Daubert, it is now clear that the lower courts have applied it vigorously to exclude expert testimony." $" 137$

Since the plaintiff ordinarily has the burden of proof in tort litigation, this aggressive invocation of the judge's new role as guardian of the purity of scientific evidence has had a disproportionate impact on plaintiffs. With remarkable speed, judges have gone far beyond throwing the clinical ecologists out of the courtroom. ${ }^{138}$ Impressed by artful defense counsels' smoke screens, they are now excluding testimony of well-regarded experts. ${ }^{139}$ A plaintiffs' attorney must prepare not only to establish an expert's qualifications, but also to convince a skeptical trial judge that the testimony supports a scientifically reliable conclusion based upon scientifically reliable

137. Jeffry D. Cutler, Implications of Strict Scrutiny of Scientific Evidence: Does Daubert Deal a Death Blow to Toxic Tort Plaintiffs?, 10 J. EnVTL. L. \& LiTig. 189, 214 (1995) (“[I]t doesn't take a rocket scientist to figure out that a four or five part test including 'general acceptance' as one factor will be more difficult to meet than a test based on 'general acceptance' alone.").

138. In the mid-1980s, the science of clinical ecology appeared to be the answer to the causation conundrum for plaintiffs' attorneys. Professor Elliott described the phenomenon as follows:

For a price, some clinical ecologists will testify that exposure to even very small amounts of a wide range of chemicals suppresses the immune system, thereby weakening the body's ability to ward off disease. This weakening, in turn, allegedly makes the plaintiff vulnerable to virtually all diseases known to humankind, including "nervousness," "malaise," and other conditions that present only subjective symptoms.

E. Donald Elliott, Toward Incentive-Based Procedure: Three Approaches for Regulating Scientific Evidence, 69 B.U. L. Rev. 487, 490 (1989); see also Peter Huber, A Comment on Toward Incentive-Based Procedure: Three Approaches for Regulating Scientific Evidence by E. Donald Elliott, 69 B.U. L. REv. 513, 515 (1989). Even before Daubert refined their screening function, the courts never seriously entertained claims based heavily upon the testimony of clinical ecologists.

139. For an excellent example, see Professor Beecher-Monas's thorough and devastating critique of the post-Daubert Eighth Circuit Court of Appeals' opinion in Wright v. Willamette Indus., Inc., 91 F.3d 1105 (8th Cir. 1996). Erica Beecher-Monas, The Heuristics of Intellectual Due Process: A Primer for Triers of Science, 75 N.Y.U. L. REV. 1563, 1637 (2000). 
data, and that the conclusion fits the legal requirements for establishing causein-fact. ${ }^{140}$ If the plaintiffs' attorney fails, everyone goes home, and no one knows whether the plaintiff was a victim of cruel fate or the defendant's possibly unconscionable conduct. Even if the attorney succeeds, the judge and jury must sit through days of confusing and conflicting expert testimony, at the end of which the jury may still decide that the plaintiff did not carry the burden of proof. ${ }^{141}$

Giving judges the opportunity to easily replace a reading of the law with their personal preferences undermines the entire American judicial system. This is very dangerous, as Hamilton noted in The Federalist No. 78: "The courts must declare the sense of the law; and if they should be disposed to exercise WILL instead of JUDGMENT, the consequence would equally be the substitution of their pleasure to that of the legislative body."142 The role of the judge was supposed to be that of a rule-enforcer. The rules were to be clearcut in such a way that bias would have little opportunity to rear its ugly head. But Daubert has provided just that opportunity.

Some judges have recognized this and refused to engage in the amateur science that Daubert allows. An Arizona Supreme Court Justice, Stanley Friedman, in a case where evidence had been excluded in a lower court's Daubert hearing, wrote, "Multi-factored, 'flexible' tests of the sort announced in Daubert are more likely to produce arbitrary results than they are to produce nuanced treatment of complex questions of admissibility." 143

However, it is not the case that Daubert judges are a malicious lot seeking to protect the interests of industry at the expense of the common man. The problem with Daubert is that it allows judges' subconscious biases and preconceptions to shape their decision-making in a dramatic way. To the extent that the court has a bias or preconception one way or another in a civil dispute, it would not be surprising to see that bias play itself out in a negative evaluation of the proof offered by one side. ${ }^{144}$ It is human nature to look

140. See Harvey Brown, Eight Gates For Expert Witnesses, 36 Hous. L. Rev. 743 (1999) (detailing eight "gates" through which a proponent of expert testimony must navigate in order to demonstrate that the testimony is admissible); see also Beecher-Monas, supra note 139.

141. See Thomas O. McGarity, On the Prospect of "Daubertizing" Judicial Review of Risk Assessment, 66 LaW \& Contemp. Probs. 155, 170 (2003).

142. The Federalist No. 78 (Alexander Hamilton).

143. Logerquist v. McVey, 1 P.3d 113, 126 (Ariz. 2000).

144. The problem of disobedient federal judges has emerged in numerous contexts. See, e.g., Adam Liptak \& Ralph Blumenthal, Death Sentences in Texas Capital Cases Try Supreme Court's Patience, N.Y. Times, Dec. 5, 2004, at 40 (quoting former Third Circuit Chief Judge John Gibbons: "The Fifth Circuit went out of its way to defy the Supreme Court on this [death penalty-related issue]. The idea that the 
favorably at data that reinforces one's preexisting worldview. It is harder to evaluate facts objectively. ${ }^{145}$ What is unfortunate is that different factfinders can draw different inferences about what is important, and the current jurisprudence seems to signal the death of inferential proof. ${ }^{146}$ Next could be a lawyer's ability to define his own case. ${ }^{147}$

\section{Even Peer-Reviewed Evidence is Excluded Under Daubert}

Recall that the original reasoning by the Supreme Court in Daubert was that the Frye peer-review standard was too stringent and prevented novel theories from being offered. ${ }^{148}$ Thus, the point of the case was to expand the

system can tolerate open defiance by an inferior court just cannot stand."); see also JAY E. AUSTIN ET AL., Envtl. Law Inst., Judging NePA: A "Hard Look" at Judicial Decision Making Under the National Environmental Policy Act (2004), http://www.endangeredlaws.org/downloads/ JudgingNEPA.pdf (revealing a wide division between Republican and Democratic appointees in rulings in NEPA cases).

145. It is also hard to reconcile the unlimited trust placed in a trial court on Daubert matters with the micro-managing of judges that is now the vogue. In areas like sentencing and even the supervision of class actions, the trend is in the opposite direction.

146. For example, Cross v. Alpha Therapeutic Corp. (In re Factor VIII or IX Concentrate Blood Prods. Litig.), No. CIV.A.94-0382, 2000 WL 282787 (E.D. La. Mar. 14, 2000), is a very complex class action case involving alleged reinfection of an HIV positive person through the medium of the defendant's intravenous solutions. The case is significant because it involves a "new theory" expert testimony case under Daubert. Id. at *13. The district court denied a defendant's motion for summary judgment based on its expert testimony that there was no evidence that reinfection of HIV occurred in humans. Id. Literally in the motion papers, the plaintiffs presented a report which documented the first case of an HIV positive patient to actually be reinfected with a second strain of HIV. Id. At the time of hearing the potential rate of error was unknown, the actual test performed had not been subjected to peer review, and there was no evidence that it was generally accepted in the scientific community. Id. However, the plaintiffs presented other evidence in the form of papers by their own expert witness and others that seemed to illustrate the existence of the reinfection theory. $I d$. The court assumed, for purposes of the summary judgment motion, that the reinfection theory would survive a Daubert challenge as to reliability. Id. However, the court held that the proffered expert evidence did not survive the Daubert relevancy test because the plaintiffs could not present evidence that the plaintiff had actually been reinfected or that his illness would have proceeded differently from the singly-infected individual because of reinfection. Id. The case does not set the standards for a "new theory" case but is one of the first to even consider the matter.

147. In considering whether a ladder was unreasonably dangerous in design, the district court in Clark v. R.D. Werner Co., No. CIV.A.99-1426, 2000 WL 666380 (E.D. La. May 18, 2000), rejected the testimony of plaintiff's metallurgical expert. $I d$. at $* 5$. The court concluded that the issue in the case was bad design, and not metal failure. $I d$. The metallurgist's specialty was in bicycle failure. $I d$. at $* 4$. The trial court rejected the metallurgist's testimony because he was not a mechanical engineer, had never designed or overseen the assembly of the stepladder, had never subjected any ladder-much less the ladder in question - to a full protocol of tests required by industry standards, had not served on any committees creating the standards, had not studied in the field of accident reconstruction, and had never done metallurgical testing on any ladder including the ladder in question. $I d$.

148. Daubert, 509 U.S. at 589. 
amount of allowable evidence beyond mere peer-reviewed evidence. The fact that peer-reviewed evidence that passes the Frye standard is now being excluded in Daubert hearings shows the perverse fashion in which Daubert has been interpreted and applied by the federal judiciary.

For example, in Castellow v. Chevron USA, ${ }^{149}$ a deceased gas station attendant's wife and daughter brought suit against two of the decedent's employers alleging that exposure to benzene caused his cancer. The district court rejected the plaintiffs' experts' testimony of the link between benzene and acute myelogenous leukemia (AML) simply because the experts used an exposure model to determine the decedent's exposure to the chemical. ${ }^{150}$ The court agreed with the defendant's contention that '[plaintiffs' experts'] reliance on 'modeling' to calculate [decedent's] lifetime benzene exposure is an inappropriate methodology." 151 According to the court: "Although [p]laintiffs insist that the modeling technique is an acceptable scientific methodology and well suited to cases like this one, the court is not persuaded that the record supports that assertion when modeling is used to justify causation opinions in a tort claim." ${ }^{152}$ The judge in the case rejected modeling as an acceptable scientific methodology even though it is widely accepted in the field. Plaintiffs even produced a publication by the American Industrial Hygiene Association ("AIHA") in which modeling is described and advocated. ${ }^{153}$ As is evident, some judges use Daubert to exclude evidence that is even accepted in the scientific community. This is clearly contrary to the Supreme Court's holding.

Judge John Parker's exclusion of expert testimony (and subsequent granting of summary judgment) in Chambers v. Exxon Corp. ${ }^{154}$ is a glowing example of abuse of Daubert. In that case, a worker at an oil refinery who was exposed to benzene over a five-year period contracted an extremely rare form of cancer: chronic myelogenous leukemia (CML). ${ }^{155}$ Plaintiffs produced Dr. Peter Infante, the former Director of the Office of Standards Review at OSHA and a professor in Environmental and Occupational Health. ${ }^{156}$ Dr. Infante had authored a 1977 study concluding that benzene caused

149. 97 F. Supp. 2d 780 (S.D. Tex. 2000).

150. Id. at 793 .

151. Id. at 786 .

152. Id. at 789

153. Id.

154. 81 F. Supp. 2d 661 (M.D. La. 2000).

155. Id. at 663 .

156. Id. at 664 . 
CML. ${ }^{157}$ The basis of Judge Parker's exclusion of this expert testimony is remarkable:

The disease from which Mr. Chambers suffers, chronic myelogenous leukemia, develops in the general population. It develops in those that have been exposed to benzene and those that have not. Without a controlled study, there is no way to determine if CML is more common in people who are exposed to benzene than those who are not. Therefore, in a case such as this, the most conclusive type of evidence of causation is epidemiological evidence. Epidemiological studies are necessary to determine the cause and effect relationship between an agent, in this case exposure to benzene, and a disease, CML. Epidemiological studies can be defined as the branch of medicine that deals with the causes, distribution, and control of disease in humans. ${ }^{158}$

In dismissing the case, Parker concluded that 'plaintiffs' experts have not offered an epidemiological study that conclusively establishes a statistically significant risk of contracting CML from exposure to benzene." ${ }^{59}$ But, because CML is so rare, there were not enough sufferers of the disease to do a blue-collar study of all workers in the field. ${ }^{160}$ So, what Judge Parker wanted is a "controlled study" where plaintiffs' experts take 100 healthy people, put fifty in each room, and spray fifty of them with benzene (presumably without telling them to keep the experiment truly controlled). Then the scientists can see which group contracts CML and suffers a horrible death so that this evidence can be presented in court. And only this study will satisfy Judge Parker's desire for "good science." Unfortunately, Daubert provides the opportunity for judicial adventurism into areas that are best-suited for those with a scientific education. ${ }^{161}$

Also consider Newman v. Motorola, Inc., ${ }^{162}$ a cellular phone cancer case. There, the judge blocked plaintiffs from presenting their expert testimony to the jury. ${ }^{163}$ As two scholars have noted:

157. $I d$.

158. Id. at 663-64 (citation omitted).

159. Id. at 664

160. Id. at 664 n.3.

161. This reasoning did not stop with the district court. The Fifth Circuit affirmed the exclusion, agreeing that the lack of epidemiological studies made the evidence unreliable. See Chambers v. Exxon Corp., No. 00-30559, 2001 WL 43538 (5th Cir. Jan. 5, 2001). According to the Fifth Circuit, "because Chambers failed to demonstrate that his experts would present reliable data that benzene caused his CML, the district court acted within its discretion when it excluded the testimony of Chambers' causation experts." $I d$. at $* 2$. This shows how a lack of any meaningful appellate review only crystallizes and promotes Daubert abuse.

162. 218 F. Supp. 2 d 769 (D. Md. 2002).

163. Id. at 783 . 
While limits to peer review have been widely acknowledged, [Judge] Blake's skepticism and forensic investigation of the correspondence between Hardell and various journal editors places her judgment on what might appear to be a scientifically unaccountable basis. In a discussion of problems with the "use and abuse" of research subpoenas and judicial misconceptions of the role of scientific peer review Sheila Jasanoff explained that:

[s]cientific peer review is likely to differ markedly in its objectives and impact from review carried out by an expert in a litigation context. In legal review, the goal is neither to make good work better nor to retrieve what might be of value from work of lesser significance. It is instead, to seek to aggressively as possible discredit the proffered evidence and to deploy in the process all the skeptical resources that experts specifically engage for this purpose can muster.

Having challenged the circumstances surrounding the publication of Hardell's work, Blake continued the critical assessment of Hardell's claims: "The fact of publication, of course, does not eliminate the need to examine the results and methodology of the study, keeping the inquiry focused on relevance and validity as it relates to the causation opinions offered in this case." Blake criticized Hardell's "methodology," highlighting: problems of recall bias, lack of a demonstrated doseresponse relationship, the relationship of ipsilateral causation to general causation; problems with sub-group comparisons; and lastly, the reliance of a methodology for testing laterality, that "has not been used by any other scientist proffered to the court ... nor . . been replicated."

Furthermore, Blake's references to testing and replication provide a good example of the flexible ways ideal images of the scientific method can be used in legal settings to help deconstruct or marginalize particular forms of expertise. For example, Blake suggested that Hardell's work had not been replicated because " $[\mathrm{t}] \mathrm{he}$ Inskip and Muscat studies [two alternative epidemiological studies] which tested laterality by other means and admittedly with a smaller number of people do not show increased risk."

Sociologists of science, most notably Harry Collins, have provided detailed accounts of how the meaning and interpretation of an experimental replication are highly negotiable and often controversial. Blake engages in precisely this kind of interpretive exercise when she accords a sufficient degree of similarity to all of the epidemiological studies in question which allows them to be characterized as a failure to replicate Hardell's findings. Notwithstanding this view, it would have been open to Blake to dismiss Hardell's work even if the Inskip and Muscat studies had supported his findings. The studies could have been distinguished, drawing upon Blake's categories, on the grounds that they tested laterality "by other means" and with a "smaller number of people."

Blake's critiques of the testing and replication also demonstrate the way postDaubert visions of science, coupled with a tough gatekeeping ethos, can be used to restrict the entry of (novel) scientific claims. One of the general features of the mobile-telephone health debate (and no doubt many other controversies around certain risks to health) has been the difficulty in achieving standardization of study methodologies and establishing what types of scientific studies should be accorded weight in ascertaining causation. While simplistic images of the sciences are de rigueur in legal formulations and contexts (exemplified in Daubert), the "real world" science is considerably more complex. Current research into the health effects of mobile telephones exemplifies this complexity in a manner that might inform our understanding of Blake's Newman decision. 
The World Health Organization (WHO) is currently running an international epidemiological study examining the medical records of cancer patients while endeavoring to establish their past mobile-telephone use. Whatever its findings, this study will be vulnerable to future legal/methodological deconstruction by claims that its results embody an unscientific recall bias. The study's retrospective approach has already encountered criticism from epidemiologists who favor prospective methods. Prospective methods tend to start by monitoring phone use and then track future health outcomes. Prospective studies, interestingly, have limited relevance to current mobile-phone tort litigation (or regulation) as they often take decades to complete. Furthermore, even if prospective studies did indicate a positive correlation between adverse health effects and mobile phone use they may be vulnerable to challenge unless (future) plaintiffs can identify physical causal mechanisms that explain why mobile phones appear to be harmful. The debate over possible causal mechanisms for mobile telephone health problems also suffers from entrenched theoretical disagreements, and a lack of acceptance around protocols for experimental work. Somewhat ironically, these entrenched theoretical disagreements are some of the factors originally motivating policymakers, such as the WHO, to oversee the retrospective epidemiological studies.

The extended gatekeeping undertaken by Blake in Newman illustrates how Daubert-inspired quests to establish scientific truth at the pre-trial stage of litigation may assist in discouraging ongoing legal scrutiny of intransigent scientific controversies involving uncertain risks. ${ }^{164}$

Judge Blake, in this case, was engaging in just the sort of amateur scientist antics that Rehnquist warned of in his Daubert dissent. ${ }^{165}$ Daubert has enabled judges to don lab coats for a day and dismiss years of careful research by real scientists. This is clearly unacceptable. Another example is Erica Beecher-Monas's critique of the Eight Circuit's handling of science issues in Wright $v$. Willamette Industries, Inc.: ${ }^{166}$

In this toxic tort case, the plaintiffs were a family who lived a short distance from a fiberboard manufacturing plant, and suffered from headaches, sore throats, respiratory ailments, and dizziness, which they claimed were caused by emissions from the plant. It was undisputed that the plant emitted particles laced with formaldehyde, that the polluting emissions exceeded state maximum levels, and that the plaintiffs were exposed to these particles.

After a jury trial at which the plaintiffs prevailed, they were awarded $\$ 226,250$ in compensatory damages. On appeal, the Eighth Circuit overturned the jury verdict, ruling that the plaintiffs were unable to meet their burden of proving proximate cause because their expert testimony should have been excluded as "speculation." As far as the Eighth Circuit was concerned, although the plaintiffs demonstrated exposure

164. David Mercer \& Gary Edmond, Daubert and the Exclusionary Ethos: The Convergence of Corporate and Judicial Attitudes Towards the Admissibility of Expert Evidence in Tort Litigation, 26 L. \& POL'y 231, 241-43 (2004) (internal citations omitted).

165. The case, reviewed for "abuse of discretion," was affirmed by the Fourth Circuit. Newman v. Motorola, Inc., 78 F. App'x 292 (4th Cir. 2003).

166. 91 F.3d 1105 (8th Cir. 1996). 
to fiberboard particles produced by the defendant manufacturer, and that these particles were found "in their house, their sputum, and their urine, they failed to produce evidence that they were exposed to a hazardous level of formaldehyde from the fibers emanating from Willamette's plant." As support, the court cited the Federal Judicial Center's Reference Manual on "fit," apparently for the notion that plaintiffs need to "prove adequate exposure to a toxic substance that was somehow connected to the defendant." The Eighth Circuit's ruling stemmed from a fundamental misunderstanding of basic scientific theory, namely elementary principles of metabolism and threshold response. ${ }^{167}$

These cases show how members of the judiciary can and do abuse Daubert. There are many reasons why the judiciary might want to prevent cases from going to trial. A bias toward industry, a starved budget and subsequent need to clear dockets, inexperienced trial judges, and the rise of the managerial judge all provide incentives to prevent a person's right from having his or her claim heard by a jury. And Daubert provides the tool.

\section{Doctored Daubert: The Effects on the Legal System AND SOCIETY}

It has been established that the combination of motive and opportunity has indeed led to Daubert's abuse. The effect of this abuse has been a tremendous impact upon the judicial system, far beyond what anyone could have imagined the Supreme Court's decision would have. For one, evidence exclusion has led to more summary judgments in favor of defendants, which has had a chilling effect on plaintiffs bringing otherwise meritorious suits. This chilling effect has extended into the realm of science as well, where scientists are refusing to testify as to their findings, so as not to be "discredited" in an American court of law. Daubert has undermined the U.S. courtroom as a mechanism for public hearing and exposing industry practices and dangerous products. Perhaps its most ironic effect is that, whereas judges who abuse Daubert think they are clearing their dockets, Daubert has led to such forum fighting between plaintiffs and defendants that more judicial resources are wasted, not conserved. The effects of Daubert abuse on collateral estoppel are also troubling, as is its politicization of the judiciary and impending creep into regulatory agency thinking. All of these repercussions are examined more closely below. 


\section{A. Evidence Exclusion and the Chilling Effect on Plaintiffs}

Despite the Supreme Court's goal in Daubert to liberalize the standards for admitting evidence to conform with the Federal Rules of Evidence, the exact opposite has happened. In 2001, the RAND Institute for Civil Justice released a study of 400 federal judicial decisions spanning a twenty-year period to determine the impact of Daubert. ${ }^{168}$ The outcome of that study showed three results: more evidence was being challenged, more was being excluded, and the frequency of summary judgment grants against plaintiffs had increased. ${ }^{169}$ Regarding the amount of testimony being excluded, one researcher found the following:

\footnotetext{
A substantial sample of such cases at the district court level shows, once again, nearly two-thirds of challenged plaintiff expertise being rejected, whereas in the small number of cases where plaintiffs have challenged defense-proffered expertise, less than half the defense proffers have been rejected. . . .

....

... [I]n state civil cases, $82 \%$ of the cases involved defendants challenging plaintiff expert proffers, and $40 \%$ of these were successful. While this rate is lower than the two-thirds victory rate for defendants in federal court, it represents a notinsignificant percentage of rejection of proffered civil plaintiff expertise on reliability grounds. This rate is almost certainly higher than the pre-Daubert rate, even though the case was not directly binding in any state court. ${ }^{170}$
}

The study conclusively tied these results to Daubert itself. According to the two researchers, "The rise in the proportion of challenged evidence excluded after Daubert provides further evidence that post-Daubert changes in standards for admitting expert evidence were more than just shifts in terminology." ${ }^{171}$

The result of more evidence being excluded was, of course, a spike in the percentage of summary judgment motions won by defendants. With many novel claims being based on recent advances in science, it is no wonder that many plaintiffs' cases rely so heavily on expert testimony. The statistics

168. Lloyd Dixon \& Brian Gill, RAND Inst. for Civil Justice, Changes in the Standards for Admitting Expert Evidence in Federal Civil Cases Since the Daubert Decision (2001), available at http://www.rand.org/publications/MR/MR1439/MR1439.pdf [hereinafter RAND STUDY].

169. Id. at 61-62; see also Margaret A. Berger, What Has a Decade of Daubert Wrought?, 95 Aм. J. Pub. Health, S59 (2005).

170. D. Michael Risinger, Navigating Expert Reliability: Are Criminal Standards of Certainty Being Left on the Dock?, 64 AlBANY L. REV. 99, 110-11 (2000) (footnotes omitted).

171. RAND STUDY, supra note 168, at 54. 
speak for themselves, with findings that " $t$ t]he percentage of summary judgment motions granted post-Daubert more than doubled. Over 90 percent of the judgments came down against plaintiffs." ${ }^{172}$ So Daubert, a decision which was to make novel claims easier, has more than doubled the amount of doors slammed to plaintiffs' attorneys seeking compensation for their clients. Daubert has severely crippled the plaintiff's right to a jury trial and has had an effect opposite of that which the Supreme Court intended.

The ABA Section of Litigation has underscored the existence of this problem. ABA research shows that the percentage of federal civil cases going to trial has dropped from $11.5 \%$ in 1962 to $1.8 \%$ in $2002 .{ }^{173}$ The conclusion: Despite the alleged litigation explosion in recent decades, the actual number of civil jury trials in federal court has steadily decreased in both percentage and actual number. ${ }^{174}$ In the Fifth Circuit, Judge Higginbotham found that the average judge presides over fourteen trials a year, with over half of them lasting less than three days. ${ }^{175}$ Civil trials especially are on the decline. There has been a 79\% decline in tort trials between 1985 and 2003, from 3600 to 800 nationally. ${ }^{176}$

It should come as no surprise that the expense of defending against Daubert motions has had a "chilling effect" upon plaintiffs. According to the RAND Study, the heightened frequency of exclusion of expert testimony resulting from Daubert could "lead plaintiffs to narrow the case, drop the case altogether, or accept a reduced settlement." "177

The socio-economic implications of this deserve mentioning. The reduced threat of a jury trial reduces the incentive for companies to reduce reckless behavior. America's entire civil justice system, which encourages all

172. Project on Scientific Knowledge and Public Policy, supra note 8, at 4 (citing RAND STUDY, supra note 168).

173. See Patricia Lee Refo, Opening Statement: The Vanishing Trial, Litig., Winter 2004, at 2, 2 , available at $\mathrm{http} / / / \mathrm{www}$. abanet.org/litigation/journal/opening_statements/04winter_openingstatement.pdf.

174. Although ABA research shows this trend in some state courts at least, some other state courts appear to be different. In New Jersey, $1.9 \%$ of all filed cases are resolved by trial. This number has remained constant from 1990 to 2004. Harvey C. Fisher, Trial Rates Down? Not on Your Life, 13 N.J. LAw., Nov. 8, 2004, at 1. Interestingly, for litigation explosion theorists, total new filings per year fell to 99,855 in 2004 from 160,465 in 1990. Id.

175. Patrick E. Higginbotham, So Why Do We Call Them Trial Courts?, 55 SMU L. Rev. 1405, 1405-06 (2002). The unfinished part of the story about declining jury trials is how few jury verdicts are allowed to stand post-trial or on appeal. E.g., Joseph T. Hallinan, In Malpractice Trials, Juries Rarely Have the Last Word, WALL ST. J., Nov. 30, 2004, at A6.

176. Leonard Post, Federal Tort Trials Continue Downward Spiral, NAT'L L.J., Aug. 22, 2005, at 1.

177. RAND STUDY, supra note 168 , at 55. 
harmed plaintiffs to bring cases with the contingency-fee arrangement (to provide access to all) and punitive damages (to punish bad behavior), seeks not only to compensate the victim but also to deter companies from harming in the first place. Clearly, the rise of the Daubert regime is undermining the basic purposes of the American civil justice system.

\section{B. Chilling Effect on Scientists}

The chilling effect extends beyond the realm of the law into the realm of science. This is perhaps one of Daubert's most unanticipated (and most dangerous) effects. Beyond suffering the personal attacks associated with a Daubert hearing, scientists are beginning to understand that the validity of their life's work will be upheld or discredited at the whim of a particular judge. This imperils not only a scientist's professional reputation but possibly even his or her funding. The Tellus Institute, in their study of Daubert, spoke to experts and scientists who confirmed this chilling effect:

David Michaels, a Professor in the Department of Environmental and Occupational Health at the George Washington University School of Public Health and Health Services and former Assistant Secretary of Energy for Environment, Safety and Health at the U.S. Department of Energy, said the Daubert process may be keeping well-regarded scientists out of an area where they could be providing a public service. "I'm concerned that scientists are hesitant to testify for fear of being drawn into a lengthy and unpleasant process where they have to defend their good names," he said. ${ }^{178}$

Daubert is scaring experts from sharing their expertise with the court. How is this good for judge, fact-finder, or society at large?

\section{Daubert Undermines the Courtroom as a Public Hearing Mechanism}

The Newman cell-phone case discussed above underscores a related but distinct public policy point regarding the effects of Daubert's abuse. Many view the tort system as filling a void left by an increasingly corporatedominated legislative and executive branch:

[W]e have failed to create adequate public forums, other than tort lawsuits in courtrooms, for citizens to express their outrage at the injurious imposition of unconsented-to risks. Only in the courtroom can citizens officially and publicly call omitted).

178. Project on Scientific Knowledge and Public Policy, supra note 8, at 13 (citations 
corporations and their officials to answer for their actions, prevent corporate harmcausers from evading public government criticism and lawsuits, expose corporate decisionmaking and publicly reprimand corporations and their decisionmakers for the harms they cause. Only in the courtroom do we acknowledge and reinstate the dignity, respect, and autonomy of the injured victims in a public way. Tort litigation provides a place for victims to tell their stories to the public and make the perpetrators listen. Tort law theoretically empowers injured victims to act, when the government does not protect their health and safety. We should not blame injured victims for utilizing the tort system as this kind of public forum, nor fault the tort system for providing it. We should praise common law tort for its tenacity, particularly in an era of bad press, lax regulatory agencies, and minimal criminal sanctions. The failures here are in the background political and legal systems, not in common law tort or with its victims. ${ }^{179}$

Daubert hearings are clearly hurting the role of the court in this aspect. ${ }^{180}$ Many Daubert decisions are unpublished, thus keeping the public uninformed about what is happening. In other words, new theories regarding the dangers of products already on the market are being suppressed. Courtrooms often provide a safety net to catch dangerous products that have slipped through the cracks of the (increasingly industry-influenced) regulatory agency. In short, Daubert is preventing scientists from blowing the whistle on products that are harming people.

\section{A Waste of Judicial Resources: The Rise in Forum Fighting}

Forum shopping. This is a favorite term of those seeking to take away one's right to a jury trial. The waste of judicial resources and so-called "litigation explosion" are a result of this. The irony is that Daubert may have contributed to the forum-fighting phenomenon (where parties spend years and countless judicial resources fighting about where a case should be tried) more than any other development in American law. ${ }^{181}$

The Frye approach, ${ }^{182}$ which uses a general acceptance test, remains important in that Daubert is still the minority view nationally. About $98 \%$ of all civil and criminal cases are litigated in state courts. ${ }^{183}$ Only sixteen states

179. Leslie Bender, Feminist (Re)torts: Thoughts on the Liability Crisis, Mass Torts, Power, and Responsibilities, 1990 DUKE L.J. 848, 861-62. here.

180. Whether or not "public forum" is a proper role for a court is a large subject that is not addressed

181. See, e.g., Jennifer Wolsing, Note, Daubert's Erie Problem, 82 InD. L.J. 183 (2007) (discussing how Daubert's ambiguity has resulted in different judicial interpretations of the admissibility of evidence between state and federal courts in the same districts, resulting in forum shopping).

182. Frye v. United States, 293 F. 1013 (D.C. Cir. 1923).

183. Marc Galanter, Beyond the Litigation Explosion, in New Directions in Liability Law 19 
have expressly adopted the Daubert standard, while nineteen states still adhere to the Frye standard. ${ }^{184}$ When looking beyond strict adoption to the actual test employed, some commentators contend that twenty-five states apply Daubert or a similar test, fifteen states (plus the District of Colombia) use the Frye test, six other states have not rejected Frye but apply Daubert factors, and four states have developed their own tests. ${ }^{185}$ Among the Frye states are populated states like California, Florida, Illinois, New York, and Pennsylvania. ${ }^{186}$ In many cases, the battle between state court and federal court is really a battle between the Frye and Daubert standards. So, with its potential for abuse (i.e., when a judge throws out scientific evidence that is generally accepted in the scientific community), Daubert has made the battle between state and federal courts the death-knell battle in many cases involving scientific evidence. This has led to the "forum-shopping versus removal" problem that is wasting an incredible amount of judicial resources. Defendants, rather than preparing a defense and moving forward with a case (which helps clear a judge's docket), now spend considerable time fighting for removal to federal court. In many cases, they do so for no other reason than to get to a jurisdiction employing Daubert ${ }^{187}$ Many judges who think Daubert is a wonderful tool to clear one's docket might be surprised to know that it is actually making their dockets more, not less, congested. Whatever time the judiciary is saving in a Daubert summary judgment, they are wasting overseeing the venue fight that Daubert creates.

Daubert has led to more litigation in other respects as well. Because of Daubert, parties are being dragged into litigation that would otherwise be left out. The fight to keep a case in state court (and away from a Daubertwielding potentially biased federal judge) might entice a plaintiff to drag additional defendants into a case in order to defeat a federal court's diversity jurisdiction. One example would be a plaintiff's lawyer joining as a defendant

(Walter Olson ed., 1988).

184. States Move to Daubert, Even When They Say They're Stuck on Frye, 30 BNA Product SAFETY \& LiaBILITY REP. 328, 328-41 (2002).

185. Alice B. Lustre, Annotation, Post-Daubert Standards for Admissibility of Scientific and Other Expert Evidence in State Courts, 90 A.L.R. 5th 453 (2001).

186. See People v. Farnam, 47 P.3d 988 (Ca. 2002); Ibar v. State, 938 So. 2d 451 (Fla. 2006); People v. McKown, 875 N.E.2d 1029 (Ill. 2007); People v. LeGrand, 867 N.E.2d 374 (N.Y. 2007); Commonwealth v. Whitacre, 878 A.2d 96 (Pa. Super. Ct. 2005); see also States Move to Daubert, Even When They Say They're Stuck on Frye, supra note 184. (2003).

187. E.g., Allan Kanner, The Problem of MDL Injunctions, 4 BNA Class Action ReP. 303, 306 
the drug-prescribing doctor in a drug liability case involving an out-of-state corporation.

\section{E. Daubert's Damage to Collateral Estoppel}

The broad discretion given trial judges to interpret science under Daubert "has created the appearance of incoherence, with courts rendering contradictory admissibility rulings despite evaluating the same testimony and applying the same factors." 188 In other words, science accepted in one Daubert hearing might be rejected in a similar hearing in a different court. This hurts collateral estoppel-and results in a waste of judicial resources.

The best known example of Daubert's "schizophrenic science" effect involves the lawsuits brought against the makers of Parlodel, a lactation suppressant. The Tenth Circuit called the situation "a counter-intuitive effect [of Daubert]," whereby different courts relying on essentially the same science may reach different results. ${ }^{189}$ In the Parlodel cases, the plaintiffs asserted that the drug caused them to suffer heart attacks, strokes, and seizures. ${ }^{190}$ As proof, they presented "case studies, animal studies, challengerechallenge data, toxicology studies and the opinions of medical professionals, including testimony from a member of the FDA's Fertility and Maternal Health Drugs Advisory Committee who had reviewed the safety of Parlodel for the federal government." ${ }^{\prime 191}$ Most of the cases had Daubert hearings, and the result was a mess. Different courts, supposedly applying the same criteria, reached drastically different results. ${ }^{192}$

One judge, who refused to exclude the evidence at the Daubert hearing, offered this critique of Daubert's abuse:

188. Note, Reliable Evaluation of Expert Testimony, 116 HARv. L. Rev. 2142, 2147 (2003); see also Hollander v. Sandoz Pharm. Corp., 289 F.3d 1193, 1206 (10th Cir. 2002).

189. Hollander, 289 F.3d at 1206.

190. Id. at 1195 .

191. Project on Scientific Knowledge and Public Policy, supra note 8, at 11.

192. For example, a significant amount of evidence was excluded in the following cases: Hollander v. Sandoz Pharm. Corp., 95 F. Supp. 2d 1230 (W.D. Okla. 2000); Siharath v. Sandoz Pharm. Corp., 131 F. Supp. 2d 1347 (N.D. Ga. 2001); Glastetter v. Novartis Pharm. Corp., 107 F. Supp. 2 d 1015 (E.D. Mo. 2000); Brumbaugh v. Sandoz Pharm. Corp., 77 F. Supp. 2d 1153 (D. Mont. 1999); Caraker v. Sandoz Pharm. Corp., 172 F. Supp. 2d 1046 (S.D. Ill. 2001). At the same time, the same evidence was not excluded in the following cases: Brasher v. Sandoz Pharm. Corp., 160 F. Supp. 2d 1291 (N.D. Ala. 2001); Eve v. Sandoz Pharm. Corp., IP 98-1429-C-Y/S, 2001 U.S. Dist. LEXIS 4531 (S.D. Ind. Mar. 7, 2001); Globetti v. Sandoz Pharm., Corp., 111 F. Supp. 2d 1174 (N.D. Ala. 2000). 
It is not part of the trial judge's gatekeeping role to determine whether the proffered opinion is scientifically correct or certain in the way one might think of the law of gravity. . . . [I]t is the fact-finder's role (usually a jury) to determine whether the opinion is correct or worthy of credence. For the trial court to overreach in the gatekeeping function and determine whether the opinion evidence is correct or worthy of credence is to usurp the jury's right to decide the facts of the case. All the trial judge is asked to decide is whether the proffered evidence is based on "good grounds" tied to the scientific method. ${ }^{193}$

Clearly, the Supreme Court needs to re-visit this issue in light of the incredible amount of confusion as to what Daubert actually instructs (or empowers) a trial judge to do. Any test that results in wildly inconsistent outcomes across the nation is not compatible with the notion of collateral estoppel in the justice system.

\section{F. Daubert Abuse Creeping into Regulatory Agencies}

Potential Daubert abuse does not only threaten our nation's courts. Regulatory agencies are starting to adopt Daubert-like standards. This of course allows the political (and possibly industry-biased) appointees at the top of the regulatory agencies to dismiss the findings of agency scientists by hiding behind Daubert. Powerful interests are basically attempting to replace science with bias, to replace policy with politics. There is evidence that they are succeeding. In 1999, an industry-funded think tank was formed with the goal of urging administrative agencies to apply Daubert standards to the science agencies rely upon to administer our nation's health, safety, and environmental laws. ${ }^{194}$ Congress responded by passing the Data Quality Act in 2000. ${ }^{195}$ The Act directs the Office of Management and Budget (OMB) to issue government-wide guidelines that "provide policy and procedural guidance to [f]ederal agencies for ensuring and maximizing the quality, objectivity, utility, and integrity of information (including statistical information) disseminated by [f]ederal agencies."196

The OMB published the final guidelines to implement the Data Quality Act in the Federal Register on September 28, 2001. ${ }^{197}$ These guidelines

193. Globetti v. Sandoz Pharm. Corp., 111 F. Supp. 2d 1174, 1177 (N.D. Ala. 2001).

194. See John J. Fialka, Panel Judging EPA's Proposed Air Regulations Receives Most of Its Funding From the Regulated, WALL ST. J., Jan. 16, 1997, at A20.

195. Pub. L. No. 106-554 app. C, §515, 114 Stat. 2763, 2763A-153 to -154 (2000) (codified at 44 U.S.C. $\$ 3516$ note (2000)).

196. $I d$.

197. Guidelines for Ensuring and Maximizing the Quality, Objectivity, Utility and Integrity of 
include "administrative mechanisms allowing affected persons to seek and obtain correction of information maintained and disseminated by the agency that does not comply with the OMB guidelines." ${ }^{198}$ Speaking about the "flexibility" of the guidelines (sounding like the flexibility of Daubert), the OMB contends that " $[\mathrm{t}] \mathrm{hrough}$ this flexibility, each agency will be able to incorporate the requirements of these OMB guidelines into the agency's own information resource management and administrative practices." ${ }^{\prime 199}$ The short meaning of this: Top agency officials now have more "flexibility" when it comes to disputing their own scientists, and "affected parties" (i.e., industry) can appeal, bringing a Daubertesque challenge to scientific agency conclusions they dislike.

There is evidence that pressure on government scientists to alter conclusions and reports based on "concerns about validity" from political appointees is growing. ${ }^{200}$ As Daubert extends into the sphere of regulation, the scientific method risks being replaced by politics within the halls of government agencies.

\section{Proposed Changes to the Daubert Paradigm}

"Proposed changes" is somewhat of a misnomer. The power to interpret Daubert in accordance with the liberal rules is within the power of every federal judge. However, given the bias that Daubert allows to occur, pleading with judges to re-examine their own preconceptions is a daunting task. However, there are a few points that can be made on the subject.

\section{A. Meaningful Appellate Review}

Meaningful appellate review needs to be introduced. Recall that under Joiner, the Court held that abuse of discretion is the proper standard of review of a district court's evidentiary rulings, and this also applies to Daubert rulings. ${ }^{201}$ Given that this is an extremely difficult standard to overcome, and that a wave of inconsistent Daubert rulings has hampered the notion of collateral estoppel, it would seem that the courts of appeal ought to have

\footnotetext{
Information Disseminated by Federal Agencies, 66 Fed. Reg. 49,718 (proposed Sept. 28, 2001).

198. Id. at 49,720 .

199. Id. at 49,719 .

200. See, e.g., Zachary Coile, Wildlife Scientists Feeling Heat: Species-Protection Data Suppressed, Many Report, SAN. Fran. Chron., Feb. 10, 2005, at A1, available at 2005 WLNR 1860628. 201. Gen. Elec. Co. v. Joiner, 522 U.S. 136, 140 (1997).
} 
greater power in overturning a trial judge's decision. A de novo standard of review seems to be in order. If for no other reason, this should occur to establish uniformity of law within the circuits, preventing another Parlodel debacle.

But Joiner need not be overturned for meaningful appellate review to be introduced. Some circuits recognize the problems created by Daubert and go beyond the abuse of discretion standard. For example, the Third Circuit uses "a 'hard look' [approach] to insure that the district court's exercise of discretion was sound and that it correctly applied the several Daubert factors." ${ }^{202}$

\section{B. A More Liberal Standard in Novel Cases}

One of the reasons for Daubert was to allow for a more liberal standard in novel cases. ${ }^{203}$ The Court seemed to agree that it was unfair for a polluter or maker of a dangerous chemical to profit from a lack of science. ${ }^{204}$ Trial judges, to give them credit, are struggling with what has been a proliferation of expert proof since the Daubert decision was handed down.

\section{A Critique of "Non-traditional" Means}

Some have suggested that courts should turn to novel means in deciding which expert testimony to admit. ${ }^{205}$ These non-traditional means "include utilization of the [Federal Judicial Center's (F.J.C.)] . . Reference Manual on Scientific Evidence, appointment of a special master, use of technical advisors, and implementation of special procedures including non-adversary presentation of expert testimony." "206 Basically, some theorists believe there should be recourse to non-judge or juror third parties. But these "solutions," like Daubert abuse, are only a means to prevent jurors from making decisions on matters.

The use of special masters and technical advisors could prove disastrous for the legal system. Who appoints the special master? If it is the judge, will not the judge appoint a person in line with his or her preconceptions? Will not

202. In re Paoli R.R. Yard PCB Litig., 35 F.3d 717, 733 (3d Cir. 1994).

203. Daubert v. Merrell Dow Pharm., Inc., 509 U.S. 579, 588 (1993).

204. Id. at 589.

205. See, e.g., Gordon J. Beggs, Novel Expert Evidence in Federal Civil Rights Litigation, 45 Am. U. L. REV. 1 (1994).

206. Id. at 75 . 
the parties involved in the litigation then fight about which special master is appointed? This solution does not seem to resolve anything. Furthermore, scientists disagree. And many scientists are paid to say things that are not even accepted by the scientific community. This point is discussed above as part of the corporate influence in science.

\section{Faith in the Jury System}

As Judge Young notes in a letter to his colleagues, "The American jury system is withering away." 207 District court judges should recognize this and shore up its defense, because "as an instrument of justice, the civil jury is, quite simply, the best we have." ${ }^{208}$ Whether it is the notion of the judge as gatekeeper, appointment of a special master, or use of a technical advisor, all of these "solutions" are tentacles of the same creature: distrust of the jury system. In response to corporate concerns that modifying the standards of admissibility might "result in a 'free-for-all' in which befuddled juries are confounded by absurd and irrational pseudoscientific assertions," ${ }^{209}$ the majority in Daubert explained:

\footnotetext{
In this regard respondent [Merrell Dow] seems to us to be overly pessimistic about the capabilities of the jury and of the adversary system generally. Vigorous crossexamination, presentation of contrary evidence, and careful instruction on the burden of proof are the traditional and appropriate means of attacking shaky but admissible evidence. . . . [T] he court remains free to direct a judgment and likewise to grant summary judgment. ${ }^{210}$
}

No one is perfect. The current attack on "activist" federal judges is indicative of our ambivalence about putting decision-making power in any one place. This sentiment is also echoed by those who fear giving juries the power to listen to two competing sides, and come to a competent conclusion. Yet the Constitution did just that, and those applying Daubert must keep that in mind.

\section{What to Do in the Meantime: Winning the Expert Battle}

An attorney is well-advised to view the Daubert hearing as an essential part of the case. Statistics show an overall affirmation rate (post-2000) of trial 
court Daubert decisions by federal appellate courts. ${ }^{211}$ A review of a significant number of post-Kumho Tire cases reversing trial court decisions indicates that reversals will often be predicated on either a complete abdication of the trial court's gatekeeping function (including classifying an expert witness as a lay witness) or a serious analytical error by the trial court. ${ }^{212}$ For much litigation (especially novel litigation), a Daubert loss can sound the death knell.

The notion of a litigation explosion ${ }^{213}$ has many federal judges intent on misusing Daubert. However, there are some techniques a plaintiff's lawyer can use to win the Daubert hearing. The important thing to remember about a Daubert hearing is that it is lawyer-driven rather than judge-driven. These are complex motions and generally the court is making a choice between two radically different presentations. The trial court generally cannot simply point to a lack of proof as it can on summary judgment. Rather the judge chooses one side's argument over the others. ${ }^{214}$

\section{A. Case and Forum Selection}

The prudent practitioner must incorporate the Daubert hearing into his or her case-selection analysis. The Daubert hearing can be one of the most expensive phases of a trial. ${ }^{215}$ Counsel should also imagine the case being assigned to the least industrious or most hostile judge in a federal district court. If plaintiff's counsel is uncertain of prevailing at that hearing, it may not make sense to bring the case in federal court. The lesson of Daubert is that expert proof needs to be part of the case-selection process. Almost no complex case should be pursued without both a competent expert and an independent assessment of the admissibility of that expert's testimony. Thus

211. Daubert in the Circuits, http://www.daubertontheweb.com/circuits.htm (last visited Mar. 22,

212. See generally id. (examining many Daubert cases under various circuits' laws).

213. See generally Arthur R. Miller, The Pretrial Rush to Judgment: Are the "Litigation Explosion," "Liability Crisis," and Efficiency Clichés Eroding Our Day in Court and Jury Trial Commitments?, 78 N.Y.U. L. Rev. 982, 1133-34 (2003) (arguing that "an unfettered commitment to 'efficiency' in the pretrial disposition context" and a resort to the "'litigation explosion' and 'liability crisis' bromides" have been eroding "systemic values" of rights to a day in court and to jury trial).

214. Similar comments have been made about patent cases, since many judges simply are unable or unwilling to take the time to get steeped in the technology of the patent, and so pick one side's brief over the other.

215. Today many of the resources that defendants used to spend on buying expert "dream teams" for trials go into expensive Daubert challenges. These challenges in some cases do more harm than good in that they educate plaintiff and force him to improve his presentation. 
it is essential that a plaintiff prepare to have his expert weather and pass the Daubert hearing.

\section{B. Discovery Strategy}

Expert opinions rarely exist in the abstract; they must be applied to facts in a particular case. One of the catch-22s in a Daubert hearing is that it might occur before the discovery hearing, when the expert has yet to obtain all of the necessary and relevant information. ${ }^{216}$ Unfortunately, many federal judges fail to appreciate, in the discovery context, the need for facts as a foundation for later expert proof. For instance, in product liability cases some courts limit discovery to the batch from which the product came from. In Kumho Tire, ${ }^{217}$ the plaintiff's expert's opinion that was stricken was about a design flaw. But the only way to test the plaintiff's theory would require discovery regarding adjustment figures. The Daubert hearing often requires knowledge of facts not yet developed by the litigation.

So what is a plaintiff's attorney to do? It is crucial to avoid Daubert hearings at the pre-discovery stages of trial. The defense is likely to move to have a Daubert hearing at the pre-discovery stage, and plaintiff's counsel must anticipate and be prepared to offer a convincing argument to the judge as to why this cannot be the case. It is important that the plaintiff's attorney make clear connections between certain discovery goals (information to be obtained) and the putative expert proof. Without first proceeding with discovery, the expert will not have a theory that is reviewable by the court at the Daubert stage.

\section{Preparing the Expert}

Plaintiff's counsel, recognizing the importance of its expert witness, must take certain actions in the screening, selection, preparation, and presentation of experts. Of course, an expert with a poor track record at Daubert hearings should be avoided. But even those who have survived Daubert challenges before must still be prepared. The expert should obviously be familiar with the four Daubert criteria and be able to defend his or her work on each point. ${ }^{218}$ And, to be on the safe side, the attorney ought to make sure that the

216. Prior to Daubert, such experts could have been, but were rarely, stricken for failing to demonstrate how their testimony would assist jurors to decide the facts of the case. See Fed. R. Evid. 702.

217. Kumho Tire Co. v. Carmichael, 526 U.S. 137 (1999).

218. The Daubert criteria: (1) whether the methods upon which the testimony is based are centered 
expert is prepared to offer the following to the trial judge in addition to the four Daubert factors:

- Proof and reasoning that the expert used an appropriate scientific methodology, including analysis of other methodologies ("trust me, judge" won't cut it) ${ }^{219}$

- Exactly what chemicals were or may possibly have been involved, and how those led to plaintiff's injuries ${ }^{220}$

- That the expert formed his or her opinion only after reading the relevant literature (and that he or she did read the relevant literature) ${ }^{221}$

- That the expert's opinion is not a hypothesis still requiring proof ${ }^{222}$

- That the expert's opinion has supporting studies, research, or literature ${ }^{223}$

- That the expert "reason[ed] from known facts to reach a conclusion ... [and did not reason] from an end result in order to hypothesize what needed to be known but what was not"224

- If the expert is asserting peer review (which he or she should be), that the work was publicized in a journal found in the Index Medicus of the National Library of Medicine (mere publication somewhere is not peer review) 225

- That the expert, if possible, actually investigated the thing at issue (as opposed to just looking at photographs or recreations-e.g., in a tire failure case) $)^{226}$

\section{Educate the Court}

Educate the court. Remember that Daubert is a lawyer-driven, rather than a court-driven, process. Usually, the trial judge is going to know what each lawyer tells him, and very little beyond that. ${ }^{27}$ Generally, the key is to proactively educate the court without sounding patronizing. Three ways to do this are through (1) a detailed complaint, (2) focused discovery, and (3) the early use of scientific requests for admission.

upon a testable hypothesis; (2) the known or potential rate of error associated with the method; (3) whether the method has been subject to peer review; and (4) whether the method is generally accepted in the relevant scientific community.

219. Ambrosini v. Upjohn Co., Civ.A. No. 84-3483 (NHJ), 1995 WL 637650 at *3 (D.D.C. Oct. 18, 1995), rev'd on other grounds sub nom., Ambrosini v. Labarraque, 101 F.3d 129 (D.C. Cir. 1996), cert dismissed, 520 U.S. 1205 (1997).

220. Claar v. Burlington N. R.R. Co., 29 F.3d 499, 502 (9th Cir. 1994).

221. $I d$.

222. Porter v. Whitehall Lab., Inc., 9 F.3d 607, 615 (7th Cir. 1993). This point underscores the importance of avoiding Daubert at pre-discovery phases.

223. Reynard v. NEC Corp., 887 F. Supp. 1500, 1505 (M.D. Fla. 1995).

224. Sorensen v. Shaklee Corp., 31 F.3d 638, 649 (8th Cir. 1994).

225. Valentine v. Pioneer Chlor Alkali Co., 921 F. Supp. 666, 671 (D. Nev. 1996).

226. Clement v. Griffin, 634 So. 2d 412, 427 (La. Ct. App. 1994).

227. However, the lawyer is well advised to research a judge's knowledge of a subject by looking at other cases he or she has presided over and any relevant background information. 
Many legal practitioners believe that a complaint should be as simple as possible, so as not to reveal too much information to the other side and annoy the court. This is true in most instances. However, in novel cases where the judge may be grappling with issues and science that he or she has yet to experience, it is advisable to write a detailed complaint so as to educate the court. The plaintiff might want to include the scientific theories and the facts supporting that science when presenting the causes of action against the defendant. True, this gives the defense more time to prepare for the Daubert hearing, but it also frames the science in the plaintiff's terms from the outset of the case, forcing the defense to react rather than put forward their own theory.

Discovery and early scientific admission requests can also educate the court about the science underlying the plaintiff's expert's assertions. If the case involves chemical exposure, include very detailed discovery requests regarding every aspect of possible exposure. While some of these requests may not even be possible for the defendant to fulfill, you have showed the judge the scientific underpinnings of your claim. This not only educates the judge about the science involved in your claim, but also shows the judge that a pre-discovery Daubert hearing is not a feasible option, as your expert is seeking specific facts upon which to build his or her opinion.

\section{E. Educate Yourself}

It is also important for attorneys facing Daubert challenges to educate themselves. First, an attorney should be able to grasp the science on the issue and actively try to educate himself or herself beyond that. Second, it is important for the attorney to understand the underlying methodology of the science, so that he or she can better defend its validity. If judges are going to don scientist hats, then you as the attorney must do so as well.

So how does one go about this? Of course the attorney should meet with the expert (and not only to learn the science, but to test the expert). First, if the expert cannot explain the science to the attorney in a way that he or she feels comfortable with, then how well will the expert do in front of a judge or jury? Second, read. If you are suing a coal company, read the biography of a coal tycoon. Read about the history of coal production, the innovations that changed the industry, and what techniques are being used today.

The reason for self-education is clear. First, the more you know about the science, the better you can articulate a legal defense for its validity. Second, and perhaps more importantly, you want the judge to see that you know more about the science than your opposing counsel so that the judge turns to you, 
and not your opponent, for clarification. This of course will be in the back of the judge's mind when the judge rules on which side's science to adopt.

It is also important to understand the essential characteristics of valid science:

1. Science seeks the systematic organization of information about the world, and in so doing discovers new relationships among natural phenomena.

2. Science endeavors to explain why phenomena occur and why they are related.

3. Systematic organization of information and explanation of phenomena also characterize other forms of knowledge, such as mathematics and philosophy, but science is further identified by a third characteristic - scientific explanations must be formulated in a way that makes them subject to empirical testing. An explanation or proposition that cannot be tested and potentially proven false simply is not scientific. In fact, falsifiability in many ways is the "criterion of demarcation" that sets science apart from other kinds of knowledge. ${ }^{228}$

One should also be aware of the four steps for testing hypotheses:

1. A hypothesis must be examined for internal consistency. A proposition that is illogical or self-contradictory on its face should be rejected.

2. A hypothesis must be examined to see if it really provides insight and understanding into why observed phenomena occur. Ad hoc hypotheses developed to fit a known set of facts typically have little explanatory power.

3. A new hypothesis must be reviewed for consistency with other hypotheses and theories already accepted as valid to see whether it represents any real improvement over well-established alternatives. Lack of consistency with accepted knowledge does not mandate rejection, but it does call for great caution.

4. The final, and most important step in testing a hypothesis is empirical corroboration. The need for testing hypotheses empirically is best illustrated by examples of what typically happens to ideas that get widely promoted even though they lack empirical support. Some scientists refer to this kind of work as "pathological science," characterized by a fixation on effects that are difficult to detect, a readiness to disregard prevailing ideas and theories, and an unwillingness to conduct meaningful experimental testing. Cold fusion is a classic example. ${ }^{229}$

\section{F. Use Daubert Against Them}

Fight fire with fire. Plaintiffs should themselves consider aggressively using Daubert challenges. Daubert has long been considered a gift to

228. Karl R. Popper, The Logic of Scientific Discovery § 6 (Karl R. Popper trans., Basic Books, Inc. 1959) (1934).

229. Bert Black, Winning The Expert Wars in the Age of Daubert (ALI-ABA Course of Study July 19, 1996), WL SB16 ALI-ABA 13 (1996). 
defendants at the expense of plaintiffs. But it is not inconceivable for a plaintiff to use Daubert to its advantage. If the defendant seeks a Daubert hearing on a plaintiff's witnesses, then the plaintiff should do the same to the defendant (in certain cases). First, this provides the opportunity to strike bad defense experts, of which there are many. Many defense "scientists" are little more than paid industry spokespersons. Expose them and the money trail. The second advantage of a plaintiff's Daubert challenge is that it generally forces the trier of fact to be more evenhanded in his or her assessment of scientific evidence. This is especially important when going before a judge with a perceived industry bias.

\section{Conclusion}

Daubert has grown to be a monster in the realm of civil litigation. The decision was meant to ease restrictions regarding barriers to scientific evidence, but empirical studies have shown that the exact opposite has happened. This was hailed by some as a means to clear dockets and stop a "litigation explosion," but the forum fighting that has resulted has only made matters worse. With each attempt by the Court to revisit Daubert, the monster only grew more heads, becoming more unwieldy and confusing. Now, with collateral estoppel in jeopardy, a chilled plaintiffs' bar and scientific community, and the very purposes of the civil justice system in jeopardy, clarification is essential.

However, only an imprudent attorney will wait for the Daubert hydra to be slain in a judicial decision of Herculean proportions. Until that time, there are active steps plaintiffs' attorneys can take to protect their clients' access to the courts. The dialogue surrounding what constitutes good science has been controlled by industry for too long. It is time for the plaintiffs' bar to put forth a passionate defense of objective, fact-driven science, and fight fire with fire. For the civil justice system, the stakes could not be higher. 